\title{
ANALISIS POTENSI WISATA DESA DENGAN KERANGKA 6A STUDI KASUS DESA NGAJUM, MALANG
}

\author{
Agung Yoga Asmoro', Thamrin B. Bachri ${ }^{2}$, Alditia Detmuliati ${ }^{3}$ \\ ${ }^{1}$ Akademi Pariwisata Nasional, Banjarmasin, Indonesia, agungyoga@gmail.com \\ ${ }^{2}$ Sekolah Tinggi Pariwisata Bandung, Bandung, Indonesia, thamrinbachri@gmail.com \\ ${ }^{3}$ Politeknik Negeri Sriwijaya, Palembang, Indonesia, alditiadetmuliati@gmail.com
}

\begin{abstract}
ABSTRAK
Histori Artikel

Submitted:

25 September 2020

Reviewed:

1 Oktober 2020

Accepted:

14 Oktober 2020

Published:

15 November 2020

Penelitian ini bertujuan untuk memetakan potensi wisata baik dari sisi produk maupun pasar wisata sebagai langkah awal dari pengembangan kepariwisataan di Desa Ngajum. Penelitian ini merupakan communitybased research yang diimplementasikan dengan pendekatan Participatory Action Research. Analisis dilakukan melalui pendekatan komponen produk wisata $6 A$ 's tanpa mengabaikan analisis pasar wisata. Temuan penelitian ini adalah bahwa Desa Ngajum memiliki potensi wisata yang belum tergali. Kekurangan pada sisi komponen attractions dan available packages akan dapat teratasi dengan dikembangkannya atraksi wisata buatan pada lahan A, terdapat potensi aktivitas ekowisata pada lahan B, agrowisata pada perkebunan kopi rakyat, wisata spiritual di Padepokan Soerjo Alam, serta potensi kolaborasi factory tour dengan Pabrik Susu Greenfield. Potensi ini harus dirancang bertahap agar mendapatkan hasil yang optimal bagi masyarakat dengan melibatkan peranan Bumdes dan Pokdarwis sebagai aktor utama. Pada akhirnya komponen amenities sudah cukup baik, sedangkan activities akan selaras dengan pengembangan attractions. Adapun komponen accessibilities dan ancillary services merupakan komponen produk wisata yang sudah dapat dikategorikan dalam kondisi baik.
\end{abstract}

Kata Kunci: Produk Wisata; Analisis Pasar Wisata; Wisata Desa; Ngajum

\section{ANALYSIS OF RURAL TOURISM POTENTIALS USING 6A FRAMEWORK A CASE STUDY IN NGAJUM VILLAGE, MALANG}

\begin{abstract}
This study aims to map tourism potential both in terms of tourism products and markets as an initial step in developing tourism in Ngajum Village. This research is community-based research implemented using the Participatory Action Research approach. The analysis was carried out through 6A's tourism product component approach without disregarding the tourism market analysis. The findings of this study are that Ngajum Village had untapped tourism potentials. Weaknesses in the components of attractions and available packages will be resolved by developing artificial attraction on land $A$, the potential for ecotourism activities on land B, agro-tourism on people's coffee plantations, spiritual tourism in Padepokan Soerjo Alam, as well as the potential for factory tour collaborations with Greenfield Dairy Factory. These potentials must be designed in stages to obtain optimal outcomes for the community by involving the roles of BUMDES and Pokdarwis as the main actors. In the end, the amenities component is considerably good, while the activities will align with the development of the attraction. The accessibilities and ancillary services are in good condition.
\end{abstract}

Keywords : Tourism Product; Tourism Market Analysis; Rural Tourism; Ngajum 


\section{PENDAHULUAN}

Undang-Undang RI No 6 Tahun 2014 Tentang Desa yang diundangkan tanggal 15 Januari 2014 lalu menjadi tonggak awal perubahan terhadap nasib puluhan ribu desa di Indonesia. Jumlah dana desa berlipat ganda dari yang semula tidak signifikan menjadi sekitar satu miliar rupiah bagi seluruh Indonesia (Cahyono et al., 2020). UndangUndang ini memberikan payung hukum terkait otonomi langsung yang diberikan kepada desadesa dalam mengurus rumah tangganya sendiri melalui aliran dana desa yang dikirimkan langsung dari APBN ke daerah/kabupaten dan selanjutnya ke rekening desa dengan jumlah yang signifikan jika dibandingkan dengan anggaran dana desa pada periode tahun-tahun sebelumnya (Wardani \& Utami, 2020).

Tentu saja turunnya dana desa diharapkan dapat mendorong desa untuk dapat melakukan perubahan agar meraih kemajuan lebih baik. Walau pada kenyataannya, dana desa ini bukan tanpa permasalahan. Penggelapan Dana Desa sebesar Rp400 juta yang dilakukan oleh seorang oknum bendahara desa (Wardani \& Utami, 2020), adalah satu potret permasalahan ini. Secara nasional tercatat sedikitnya terjaring 184 tersangka dari 181 kasus korupsi dana desa dengan nilai kerugian sebesar Rp 40,6 miliar (Fauzanto, 2020). Terlepas dari berbagai permasalahan yang ada, banyak pula contoh kesuksesan pemanfaatan dana desa yang bisa kita amati, diantaranya seperti yang terjadi dalam pelaksanaan pengelolaan dana desa yang memberikan pengaruh terhadap efektivitas program desa sejahtera mandiri (Sunardi \& Lesmana, 2020), peningkatan taraf hidup dan keterampilan masyarakat (Ashar \& Agustang, 2020), dan tentunya pemanfaatan untuk pengembangan wisata desa/desa wisata (Fikri \& Septiawan, 2020).

Fenomena makin maraknya pengembangan desa wisata/wisata desa ini memang berjalan selaras dengan diberlakukannya UU Desa (Aly, 2019) dalam (Asmoro, Aly, et al., 2020). Bahkan di Jawa Timur saja terdapat 479 desa yang sudah mengembangkan pariwisata di ruang lingkup wilayahnya (CNN Indonesia, 2020). Dalam praktiknya, desa melakukan pengembangan kepariwisataan dalam ruang lingkup desa melalui pengelolaan 3 (tiga) lembaga yang berbentuk (1) Kelompok Sadar Wisata (Pokdarwis), (2) Koperasi, dan (3) Bumdes (Kementerian Pariwisata, 2019, pp. 14-15), dimana praktik pengelolaan desa wisata yang dilakukan oleh Pokdarwis diantaranya dilakukan oleh Desa Ambengan di Kabupaten Buleleng (Arcana \& Wiweka, 2015), Desa Wisata Nglanggeran (Hermawan, 2017), atau Desa Wisata Kebonagung di Yogyakarta (Haryanto, 2014). Sementara pengelolaan dalam bentuk Koperasi dapat ditemukan pada Desa Kasongan (Daher, 2016), Desa Candirejo (Farhan, 2018; Pradhana, 2012), maupun Desa Wisata Gubugklakah (Febriana \& Pangestuti, 2018). Sedangkan pengelolaan desa wisata yang dilakukan oleh Bumdes kita dapatkan di Desa Sekapuk (Asmoro \& Aziz, 2020), Desa Belik (Rini \& Tarigan, 2020), dan Desa Ponggok di Klaten (Subehi et al., 2020).

Desa Ngajum adalah salah satu desa di Kabupaten Malang yang berlokasi di perlintasan jalur wisata Malang - kawasan wisata religi Gunung Kawi. Saat ini upaya pengembangan pariwisata di Desa Ngajum masih dalam tahap wacana. Berdasarkan wawancara awal dengan pihak pemerintah Desa Ngajum ditemukan informasi bahwa pada tahun 2020 pihak pemerintah desa sudah mengalokasikan anggaran untuk pengembangan wisata kolam renang di Desa Ngajum, namun sehubungan dengan pandemi covid, maka anggaran tersebut harus dialokasikan untuk penangangan pandemi.

Namun demikian, pengembangan pariwisata tentu haruslah membutuhkan tahapan perencanaan yang komprehensif (Rahmafitria et al., 2020; Tosun \& Timothy, 2001). Dalam konteks desa, hal ini untuk mencegah potensi permasalahan di masa yang akan datang terkait dengan ketidaksesuaian sumberdaya, serta pertanggungjawaban alokasi dana desa sebagaimana yang juga telah terjadi pada desadesa lainnya (Fauzanto, 2020), sehingga dalam penyelenggaraan pemerintahan, pemerintah desa haruslah mematuhi azas-azas penting, yaitu (1) kepastian hukum, (2) tertib dalam menyelenggarakan pemerintahan, (3) tertib 
dalam kepentingan untuk umum keterbukaan, (5) proporsionalitas, profesionalitas, (7) akuntabilitas, (8) efektivitas, (9) kearifan lokal, (10) keberagaman, dan (11) partisipatif (Undang-Undang RI No 6 Tahun 2014 Tentang Desa, 2014). Azas-azas ini lah yang seharusnya menjadi landasan di dalam menyelenggarakan pemerintahan desa (Fikri \& Septiawan, 2020).

Di sisi lain perencanaan pariwisata juga telah berevolusi dan bermigrasi dari hanya sekedar perencanaan ke suatu kawasan liburan yang dilakukan saat waktu senggang, ke model perencanaan yang lebih kompleks. Sebut saja realitas fenomena "over tourism" (Butler, 2019; Wall, 2020), pergeseran dari konsep waktu bebas dan tidak bekerja menjadi konsep pariwisata holistik (C. Costa, 2019) karena para wisatawan senantiasa terhubung secara digital ke pekerjaan mereka sepanjang waktu bahkan di saat mereka berwisata (Tanti \& Buhalis, 2017), serta iklim kompetisi pariwisata yang semakin tinggi dimana keberhasilan destinasi semakin bergantung pada kesan mendalam di benak pengunjung (potensial dan aktual) untuk mendapatkan posisi kompetitif (C. Costa, 2019, 2020). Namun satu hal yang tetap sama adalah, bahwa proses identifikasi adalah merupakan salah satu tahapan awal dari sebuah perencanaan (Pontoh \& Kustiwan, 2009) untuk "mencari, menemukan, mengumpulkan, meneliti, melakukan pendaftaran/pendataan, dan mencatat informasi dari lapangan" (Pusat Bahasa Departemen Pendidikan Nasional \& Tim Redaksi Kamus Besar Bahasa Indonesia, 2007).

Studi identifikasi wisata bukanlah barang baru, sudah ratusan atau bahkan ribuan studi identifikasi wisata yang telah dilakukan dengan berbagai peruntukan kepentingan, diantaranya (Maulany et al., 2018; Sriwi \& Hulfa, 2019) yang melakukan studi untuk mengetahui potensi obyek ekowisata, berupa data biofisik dan budaya masyarakat; atau (Atmoko, 2014; Priyanto, 2016; Susyanti \& Latianingsih, 2013) yang melakukan studi untuk mengidentifikasi potensi suatu desa untuk menjadi desa wisata. Pengidentifikasian potensi wisata alam dan memberikan penilaian terhadap DTW alam pada TN Ujung Kulon pernah dilakukan oleh (Komarani et al., 2015); juga (Tyas \& Damayanti, 2018) yang mengeksplorasi potensi pengembangan desa wisata batik; dan pengidentifikasian potensi wisata untuk dimanfaatkan sebagai modal pengembangan pariwisata berbasiskan masyarakat (Sutedjo, 2019).

Sejauh ini tidak ditemukan satu studi yang pernah dilakukan terkait identifikasi potensi wisata di Desa Ngajum. Adapun beberapa penelitian yang pernah dilakukan di Desa Ngajum (Fatima et al., 2019; Khasanah \& Susilowati, 2017; Sita Dewi \& Yulaika, 2019),kesemua studi tidak berkaitan dengan pariwisata sama sekali. Berdasarkan fakta-fakta di atas, maka diperlukan satu studi terkait dengan pengidentifikasian potensi wisata yang bertujuan untuk memetakan potensi wisata baik dari sisi pasar, maupun produk sebagai langkah awal dari pengembangan kepariwisataan di Desa Ngajum, Kecamatan Ngajung, Kabupaten Malang.

\section{LITERATUR REVIEW}

Dalam setiap pembahasan pariwisata maka kita tidak akan terlepas dari perspektif sistem pariwisata yang di dalamnya membahas tentang asal wisatawan dan tujuan wisata (Leiper, 1990), sisi pasar (Phillip Kotler et al., 2017; Morrison, 2013; Swarbrooke \& Horner, 2007) dan destinasi (produk) (Hodgson, 1990; Jeffries, 1971; Smith, 1994), sisi penawaran dan permintaan (Law et al., 2019; Song et al., 2019), dimana diantara kedua kutub ini terdapat pihak-pihak yang memainkan peran sebagai perantara, kesemuanya dipengaruhi oleh faktor-faktor lingkungan pemberi pengaruh. Jika sistem pariwisata ini diturunkan hingga tingkat desa, tetap saja tidak mengubah kompleksitas dari sistem kepariwisataan ini. Tingkat interaksi dan kompleksitas pengembangan pariwisata pedesaan tetap multi-actors. Dari perspektif penawaran dan permintaan pariwisata, pengembangan pariwisata pedesaan memerlukan integrasi berbagai faktor, termasuk kerjasama dari unit pemerintah, masyarakat warga, wisatawan, operator pariwisata, unit 
akademisi profesional, industri lokal, LSM, dan sumber daya pariwisata setempat (Ho \& Lee, 2020).

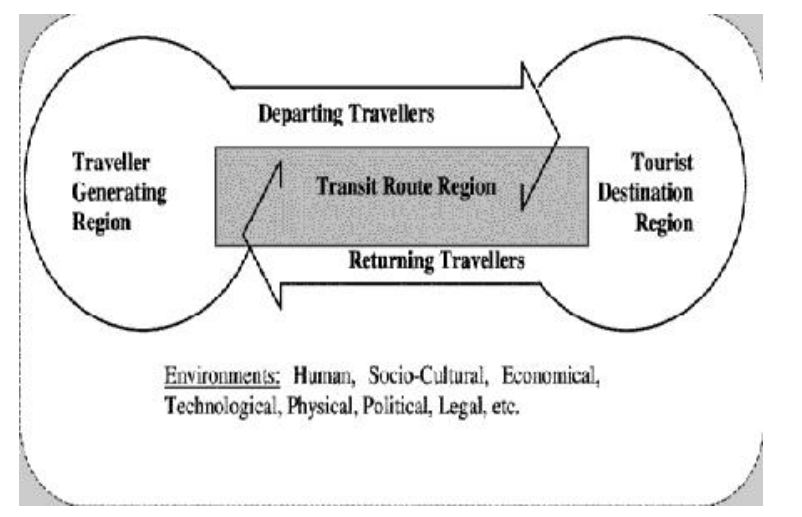

Gambar 1. Sistem Pariwisata Leiper Sumber: (Leiper, 1990)

\section{Produk Wisata}

Proses perencanaan pada dasarnya terdiri dari satu rangkaian proses yang umumnya terdiri dari (1) studi persiapan, (2) penetapan tujuan dan sasaran, (3) survei lapangan, (4) analisis dan sintesis, (5) formulasi rencana, (6) rekomendasi, (7) implementasi, dan (8) pengawasan (Inskeep, 1991, p. 28). Suatu perencanaan pariwisata bisa dikaji dari banyak pendekatan, beberapa perencana ada yang menggunakan pendekatan sistem (Carlsen, 1999), pendekatan komprehensif (Tosun \& Timothy, 2001), atau pendekatan terintegrasi (Schiefelbusch et al., 2007; Scuttari et al., 2013). Sementara perencana lain melihat dari perspektif lingkungan dan pengembangan yang berkelanjutan (Rasoolimanesh et al., 2020; Väänänen \& Komppula, 2020); pendekatan komunitas (Asmoro, Yusrizal, et al., 2020; MaldonadoErazo et al., 2020), serta pendekatan realistis (Gordon \& Champion, 2020). Namun dari berbagai pendekatan tersebut tetap akan merujuk pada komponen perencanaan pariwisata yang kurang lebih sama.

Desa wisata bisa dilihat sebagai sebuah destinasi yang terdiri dari berbagai komponen (Hall et al., 2005).Pengkategorian terhadap komponen pengembangan pariwisata ini cukup bervariasi. Inskeep mengelompokkan komponen pengembangan pariwisata ke dalam: (1) atraksi dan aktivitas, (2) akomodasi, (3) fasilitas dan layanan wisata lainnya, (4) fasilitas dan layanan transportasi, (5) infrastruktur lain, dan (6) elemen institusi (Inskeep, 1991, pp. 38-39). Sementara Cooper mempopulerkan konsep 3A's, yaitu Attractions, Amenities, Accessibilities (Cooper, 1998, pp. 105-107) yang kemudian ditambahkan satu komponen A lainnya, yaitu Ancillary pada kemudian hari. Penggunaan terminologi A dalam komponen produk pariwisata ini cukup populer, ini bisa dilihat dari penggunaan istilah yang serupa 5A's diangkat oleh Truong, yaitu attractions, access, accommodation, amenities, awareness (Truong \& King, 2009), Buhalis yang mempopulerkan 6A's attractions, amenities, accessibility, activities, available packages, dan ancillary services (Buhalis, 2000), dan Morrison dengan 10A's (Morrison, 2013, pp. 19-21).Kajian ini mencoba mengidentifikasi potensi wisata di Desa Ngajum dari perspektif 6A.

Attractions atau daya tarik wisata adalah elemen yang paling signifikan dalam sistem pariwisata yang menjadi motivasi utama wisatawan di dalam melakukan suatu perjalanan (Swarbrooke, 2002, p. 3).Atraksi dapat berupa (1) fitur dalam lingkungan alam (2) struktur bangunan dan arsitektur buatan manusia yang dirancang untuk tujuan selain menarik minat wisatawan, tetapi mampu menarik sejumlah besar pengunjung yang menggunakannya sebagai sarana rekreasi. (3) bangunan dan struktur buatan yang khusus dibangun untuk menarik wisatawan dan pemenuhan kebutuhan serta keinginan pengunjung, seperti theme park, dan (4) acara spesial yang mampu menarik minat pengunjung untuk melakukan perjalanan menuju acara spesial tersebut (Swarbrooke, 2002, p. 5).

Faktor kenyamanan wisatawan tergantung dari ketersediaan fasilitas di tempat tujuan wisata (Parthasarathy et al., 2020).Amenities mencakup seluruh komponen fasilitas yang tidak hanya memfasilitasi pengalaman wisatawan di tempat tujuan tetapi juga menambah pengalaman positifnya.Amenities secara umum meliputi fasilitas akomodasi 
dan makan minum, fasilitas ritel, dan ragam layanan wisata lainnya (Buhalis, 2000). Beberapa contoh lain dari amenities termasuk fasilitas pemenuhan kebutuhan wisatawan seperti makanan dan minuman (restoran, kafe, bar); transaksi keuangan (bank, ATM, penukaran valuta asing, pembayaran digital); akomodasi (hotel, motel, tenda); komunikasi (telepon, kualitas sinyal yang baik untuk ponsel, jaringan internet). Dalam perspektif tertentu, transportasi juga dapat dilihat sebagai bagian dari fasilitas pemberi faktor kenyamanan kepada wisatawan yang beririsan dengan parameter aksesibilitas serta amenitas lokal untuk transportasi intra tujuan (Parthasarathy et al., 2020).

Accessibility meliputi keseluruhan dari suatu sistem dan moda transportasi yang meliputi unsur-unsur terminal, rute dan jenis kendaraan (Buhalis, 2000), dimana transportasi merupakan salah satu prasyarat mendasar bagi keberadaan pariwisata yang merupakan elemen kunci yang menghubungkan wisatawan ke tujuan yang akan diakses (Tóth \& Dávid, 2010). Medlik (2003) dalam (Tomej \& Liburd, 2020) berpendapat bahwa aksesibilitas adalah satu dari tiga hal yang paling menentukan pentingnya sebuah tujuan wisata. Dimana aksesibilitas didefinisikan sebagai fungsi jarak dari pusat-pusat populasi, yang merupakan pasar wisata, dan transportasi eksternal, yang memungkinkan tujuan yang akan dicapai. Kemudahan elemen transportasi/aksesibilitas tidak hanya memudahkan pencapaian tujuan namun juga menjadi bagian dari aktivitas wisata itu sendiri.Biaya yang rendah dan jarak perjalanan relatif secara dramatis meningkatkan permintaan untuk perjalanan wisata (Halsall, 1992).Namun demikian, karakter masyarakat di Jawa Timur mengindikasikan bahwa perjalanan didominasi oleh perjalanan dalam kabupaten.Ini menandakan bahwa mayoritas pengunjung berkendara dalam radius dekat dan tidak keluar dari wilayah tempat tinggalnya (Asmoro \& Yusrizal, 2020).
Activities adalah semua aktivitas dan kegiatan wisata yang tersedia di tempat tujuan dan apa saja yang dilakukan oleh pengunjung atau wisatawan selama kunjungan (Buhalis, 2000). Aktivitas rekreasi atau wisata berkisar dari bentuk yang sangat pasif, seperti duduk santai atau menikmati pemandangan hingga jenis aktivitas yang sangat aktif (Bell et al., 2007).Namun aktivitas wisata sendiri dapat dikelompokkan ke dalam 4 (empat) kategori, yaitu "something to see, something to do, something to buy, something to learn" (Ayu et al., 2014).

Pernyataan ini memiliki pemaknaan bahwa aktivitas wisata amat berkaitan erat dengan daya tarik wisata atau destinasi wisata yang dikunjungi.Menurut Richards (2011) dalam (Remoaldo et al., 2020), kreativitas amat berperan dalam mengimplementasikan pariwisata kreatif sebagai aktivitas wisata.

Hal ini melibatkan keterlibatan aktif wisatawan dalam berbagai kegiatan kreatif di tempat yang mereka kunjungi, atau sebagai latar belakang aktivitas di mana wisatawan menempatkan diri di lingkungan kreatif yang dipilih.Masyarakat Indonesia, terlebih masyarakat desa di Jawa umumnya memiliki karakter hubungan kekeluargaan yang erat dan rukun (Yusrizal \& Asmoro, 2020).Tidak jarang ditemukan bahwa suatu perjalanan wisata dilakukan bersama-sama anggota keluarga.Kegiatan rekreasi bersama ini berperan dalam membangun dan memelihara batasan dalam keluarga, menciptakan perasaan terhubung dan mempromosikan kepentingan kolektif di antara anggota keluarga (Lehto et al., 2012).

Ketersediaan paket-paket wisata (available packages) yang telah diatur sebelumnya oleh perantara dan pengelola destinasi adalah salah satu komponen yang mempengaruhi kesuksesan destinasi wisata (Buhalis, 2000).Salah satu karakter dari destinasi wisata adalah entitas yang paling sulit untuk dikelola dan dipasarkan.Hal ini karena kompleksitas hubungan antar pemangku kepentingan (Sautter \& Leisen, 1999).Dalam sebuah destinasi, peran dari perantara ini 
amat signifikan karena seringkali desa wisata menghadapi masalah dalam memasarkan produk wisata mereka.Mereka umumnya bergantung pada perantara, seperti perusahaan swasta (biro perjalanan wisata/agen perjalanan), organisasi keanggotaan (grup/komunitas), institusi publik (pemerintah) dan organisasi nonpemerintah, untuk mendapatkan akses pasar (Forstner, 2004; Shikida et al., 2010).Namun, hubungan ini harus mempertimbangkan aspek pengetahuan lokal ketika merencanakan dan merancang paket-paket program wisata (Wearing \& Mc Donald, 2002).Selayaknya suatu hubungan apapun, dalam konteks hubungan antara desa wisata sebagai destinasi dengan perantara, intensitas dan kedekatan antara keduanya memiliki peran penting dalam membangun kepercayaan yang berujung kepada kesuksesan pengintegrasian informasi dan pengetahuan masyarakat desa ke dalam paket-paket wisata yang dipasarkan (Panyik et al., 2011).Dalam konteks penyediaan paket-paket wisata, tidak menutup pula peluang pengembangan model bisnis community-based intermediaries (CBI) yang berfungsi sebagai kepanjangan tangan dari destinasi dalam memasarkan produk desa wisatanya (Shikida et al., 2010). CBI ini selanjutnya bisa memainkan peran aktif dengan melakukan upaya pemasaran langsung kepada target pasar, ataupun tidak langsung dengan melalui perantara lain di daerah asal wisatawan potensial, atau dengan memanfaatkan ketersediaan kanal pemasaran modern (Andreopoulou et al., 2014; Bethapudi, 2015; Peña \& Jamilena, 2009).

Layanan tambahan (Ancillary services) adalah layanan yang digunakan oleh wisatawan seperti bank, telekomunikasi, pos, agen berita, rumah sakit, dan lain-lain (Buhalis, 2000).Pengembangan layanan tambahan merupakan salah satu penentu dalam mengamankan usaha wisata di daerah pedesaan yang kurang berkembang (Briedenhann \& Wickens, 2004).Jenis dan ketersediaan layanan tambahan di dalam destinasi wisata ini mempengaruhi persepsi wisatawan, baik secara positif maupun negatif (Truong \& King, 2009).Selanjutnya Harman (2007) dalam (Chahal \& Devi, 2015) menegaskan bahwa aspek layanan tambahan dan atribut kesadaran adalah hal utama yang secara signifikan mempengaruhi citra destinasi dan mempengaruhi wisatawan untuk melakukan kunjungan ulang ke suatu destinasi.Berdasarkan kenyataan ini, dalam pengembangan desa wisata komponen layanan tambahan haruslah menempati skala prioritas, sejajar dengan komponenkomponen produk wisata lainnya.

\section{Pasar Wisata}

Dalam perspektif destinasi, maka pihak pengelola Wisata Desa/Desa Wisata adalah memainkan peran sebagai DMO (Destination Management Organisations). Pemasaran destinasi adalah salah satu peran DMO terpenting (Morrison, 2013, p. 69). Perencanaan pemasaran pada destinasi seharusnya menempati prioritas bagi DMO, dan perencanaan pemasaran ini harus dilakukan secara profesional dan menyeluruh (Rahman, 2016). Pemasaran dan promosi itu membutuhkan biaya yang seringkali tidak murah, sehingga membuat pilihan yang tepat tentang pasar mana yang akan ditargetkan dan bagaimana mengkomunikasikannya dengan paling efektif adalah yang salah satu faktor terpenting, termasuk di sini adalah memikirkan tentang target pasar wisatawan digital (Goenadhi \& Rahadi, 2020). Persaingan antar destinasi sangat ketat (Alghizzawi, 2019; Ghatnekar, 2017), jadi ada kebutuhan konstan untuk selalu eksis agar mampu memikat calon wisatawan.

Pemasaran dan promosi pada destinasi ini memiliki sifat dinamis dan membutuhkan kreativitas dan inovasi tingkat tinggi (Richards \& Raymond, 2000; Tan et al., 2013). Meskipun situasi lapangan berubah dengan cepat, hal itu harus didasarkan pada pendekatan ilmiah dengan menggunakan penelitian yang solid dan prosedur sistematis yang terbukti menghasilkan hasil yang paling efektif. Keberhasilan pemasaran terjadi jika pemasaran ditetapkan dengan membidik kelompok wisatawan tertentu 
(pasar sasaran) daripada mencoba menarik pasar massal (Morrison, 2013, p. 71). Pengelola Desa Wisata selaku DMO perlu memutuskan bagaimana membagi segmen wisatawan leisure, wisatawan bisnis, atau pengunjung rekreasi dari warga sekitar ke dalam segmentasi pasar dan membuat pilihan pasar sasaran dari kelompok yang tersedia ini.

Semua pemasar tujuan memiliki berbagai cara dan metoda untuk digunakan menarik pengunjung. Cara/metoda ini kemudian dikenal sebagai 'Marketing 4Ps' (Goi, 2009; Pomering et al., 2008) yang pertama kali diusung oleh McCarthy pada tahun 1960 sebagai '4P pemasaran' termasuk produk, harga, tempat, dan promosi dan kemudian dipopulerkan oleh Kotler (Philip Kotler \& Franke, 1990). Beberapa penulis berpendapat bahwa $4 \mathrm{P}$ tradisional tidak cocok untuk pariwisata seperti yang mereka lakukan untuk produk fisik. Morrison (Morrison, 2013, pp. 94-98) menambahkan empat Ps lainnya (packaging, programming, partnership, people) untuk menangani aspek unik dari pemasaran pariwisata.

\section{METODE}

\section{Jenis Penelitian}

Kajian ini merupakan community-based research (CBR) yang diimplementasikan dengan pendekatan Participatory Action Research (PAR). Ini merupakan salah satu pilihan dalam metodologi penelitian kualitatif deskriptif dengan integrasi metode dan observasi, dokumentasi, analisis, dan penafsiran terhadap pola, atribut, dan fenomena yang diteliti (Buckles, 2019; MacDonald, 2012). PAR merupakan bagian dari penelitian tindakan, dimana pengumpulan dan analisis data dilakukan secara sistematis dengan tujuan mengambil tindakan dan membuat perubahan, sekaligus mampu menghasilkan pengetahuan praktis (Gillis \& Jackson, 2002, p. 264). Dimana tiga pilar utama PAR, yaitu metodologi riset, dimensi aksi, dan dimensi partisipasi, dilaksanakan dengan mengacu metodologi riset tertentu, yang tujuannya untuk menciptakan transformasi dalam masyarakat, dimana masyarakat memerankan peran aktif di dalam penelitian itu sendiri (Given, 2008, pp. 601-603). Tahapan penelitian ini terbagi menjadi 4 (empat), yaitu: meletakkan fondasi (laying foundation), merencanakan penelitian (planning), mengumpulkan dan menganalisis data (information gathering and analysis) dan tindakan atas hasil penelitian (acting on finding) (UIN Sunan Ampel Surabaya, 2015, p. 47).

\section{Tujuan Penelitian}

Tujuan dari metodologi kualitatif adalah untuk mendeskripsikan dan memahami, bukan untuk memprediksi dan mengontrol (Streubert et al., 1995) dalam (MacDonald, 2012). Selanjutnya penulis memposisikan temuan penelitian sebagai informasi awal bagi masyarakat dalam mengidentifikasi potensi wisata di Desa Ngajum. Hasil penelitian ini selanjutnya akan didistribusikan kepada tokoh masyarakat Desa Ngajum, untuk selanjutnya dijadikan salah satu bahan rekomendasi dalam forum diskusi Musyawarah Desa sebagai landasan awal pengembangan kepariwisataan di Desa Ngajum.

\section{Waktu dan Tempat Penelitian}

Pelaksanaan penelitian ini berlangsung pada rentang waktu 1 September 2020 sampai dengan 7 Oktober 2020, dan bertempat di Desa Ngajum, Kecamatan Ngajung, Kabupaten Malang, Provinsi Jawa Timur.

\section{Subjek Penelitian}

Subjek dalam kajian ini adalah masyarakat Desa Ngajum. Hal ini diwakili oleh Bapak Setyo Budi selaku Kepala Desa Ngajum, Bapak Yacho Nardi dan Supramono selaku Pengurus Bumdes Ngajum, dan Bapak Taofiq, selaku perwakilan tokoh pemuda yang peduli dengan pariwisata di Desa Ngajum, serta beberapa narasumber perwakilan masyarakat yang tidak berkenan dicantumkan namanya. 


\section{Data, Instrumen, dan Teknik Pengumpulan Data}

Sumber informasi penelitian di dapat dari hasil diskusi semi kasual yang terjalin antara penulis dan perwakilan masyarakat. Dalam penelitian PAR, perwakilan masyarakat warga Desa Ngajum turut berpartisipasi dalam desain penelitian, pengumpulan data, dan analisis-interpretasi data. Dalam penelitian sosial kualitatif, peneliti merupakan instrumen penelitian utama dalam pengumpulan, analisis data, dan menafsirkan data (A. P. Costa, 2020, p. 34; Merriam \& Grenier, 2019). Untuk mengumpulkan data peneliti menggunakan beberapa instrumen bantuan berupa daftar pertanyaan, daftar tema/topik pembahasan diskusi, serta daftar periksa observasi yang digunakan untuk membantu peneliti di dalam mendapatkan data-data relevan di lapangan. Instrumen tersebut selanjutnya digunakan untuk mengumpulkan data, yang dilakukan dengan beberapa metode, diantaranya: non-formal focus group discussion, observasi lapangan, wawancara semi terstruktur, dan studi dokumentasi terhadap arsip atau dokumen terkait Desa Ngajum.

\section{Analisis Data}

Analisis data merupakan suatu proses pendeteksian dan pengorganisasian data secara sistematis dengan cara pengelompokan data ke dalam kategori, selanjutnya menjabarkannya ke dalam kelompok-kelompok yang lebih kecil, proses sintesis, dan selanjutnya disusun ke dalam bentuk yang memiliki makna tertentu (UIN Sunan Ampel Surabaya, 2015). Untuk menganalisis dan menafsirkan data kualitatif, Miles dan Huberman (1994) dalam (Valsa, 2005, p. 113) mendefinisikan analisis data terdiri atas tiga unsur, yaitu: reduksi data, menampilkan data, dan verifikasi. Reduksi data di sini mengacu pada proses penyederhanaan, pengabstrakan dan transformasi data yang muncul dalam catatan lapangan. Peneliti secara terus-menerus terlibat dalam reduksi data selama penyelidikan sampai kesimpulan disajikan. Data yang muncul setelah proses ini adalah apa yang digunakan dalam analisis akhir. Menampilkan data mencakup berbagai jenis gambar, skema, grafik, dan bagan. Tujuannya adalah untuk membuat informasi yang terorganisir, tersedia, dapat diakses, dan sederhana sehingga peneliti dapat menangkap fenomena yang terjadi dan kemudian melakukan penarikan kesimpulan. Tahap akhir dari analisis data adalah kesimpulan dan verifikasi. Sejak awal, peneliti mencatat keteraturan, pola dan penjelasan. Peneliti memegang kesimpulan dengan ringan, mempertahankan skeptisisme sampai lebih eksplisit dan beralasan. Kesimpulan akhir muncul setelah proses analisis selesai (Valsa, 2005, p. 114).

\section{Keabsahan Data}

Validitas berarti kejujuran. Dalam studi kualitatif, mencapai keotentikan lebih utama daripada mewujudkan satu versi "kebenaran". Keaslian berarti memberikan informasi sosial yang adil, jujur, dan berimbang dari berbagai sudut pandang (Neuman, 2014, p. 218). Sehubungan dengan model penelitian ini adalah merupakan Community-Based Research, dimana menempatkan perwakilan masyarakat sebagai pelaku bagi penelitian tersebut, maka hal ini menghasilkan sebuah input data yang valid, yang ketika dianalisis secara partisipatoris, hasilnya benar-benar menggambarkan apa yang sesungguhnya terjadi (UIN Sunan Ampel Surabaya, 2015, p. 78).

\section{HASIL DAN PEMBAHASAN}

\section{Profil Desa Ngajum}

Desa Ngajum, merupakan sebuah desa yang berlokasi di dalam wilayah administratif Kecamatan Ngajung, Kabupaten Malang, Provinsi Jawa Timur, dengan kode desa 3507202001, dan kode pos 65164. Desa yang terbentuk sejak tahun 1900 ini memiliki luas wilayah 1.056,97 hektar, dan terletak di titik koordinat 112.534331 Bujur Timur / 8.085102 Lintang Selatan. Tipologi Desa Ngajum adalah persawahan, dengan klasifikasi desa swadaya. Adapun Desa 
Ngajum memiliki batas-batas wilayah administratif: sebelah utara berbatasan dengan: Desa Maguan dan Desa Balesari (Kecamatan Wagir); sebelah Selatan dengan Desa Jatikerto dan Desa Palaan (Kecamatan Kromengan); sebelah Timur berbatasan dengan Desa Palaan dan Desa Ngasem (Kecamatan Kepanjen), serta sebelah Barat berbatasan dengan Desa Kebobang, Desa Plaosan, dan Desa Plandi (Kecamatan Wonosari). Saat ini Desa Ngajum dipimpin oleh seorang Kepala Desa yang bernama Bapak Setyo Budi.

Menilik dari penggunaan wilayah, maka Desa Ngajum mayoritas merupakan area persawahan, yang rinciannya terdiri dari tanah sawah seluas $531,00 \mathrm{Ha}$, tanah kering 487,94 Ha, dan area fasilitas umum seluas
38,03 Ha, sehingga total luas wilayahnya adalah 1.056,97 Ha. Adapun lebih detailnya, rincian peruntukan tanah sawah terdiri dari jenis tanah sawah irigasi teknis seluas 151,00 Ha, dan sawah irigasi $1 / 2$ teknis $380,00 \mathrm{Ha}$. Tanah kering terdiri dari tanah tegal/ladang seluas $275,84 \mathrm{Ha}$, area pemukiman dengan luas 202,00 Ha, dan area pekarangan seluas 10,10 Ha. Selanjutnya, tanah fasilitas umum di Desa Ngajum terdiri atas tanah kas desa $10,88 \mathrm{Ha}$, tanah bengkok 11,85 Ha, lapangan sepakbola (untuk berolahraga) 1,00 Ha, area kantor pemerintah $0,50 \mathrm{Ha}$, kawasan pemakaman umum 5,52 $\mathrm{Ha}$, area bangunan gedung sekolah 2,00 Ha, area pertokoan seluas $0,50 \mathrm{Ha}$, fasilitas pasar $0,50 \mathrm{Ha}$, dan area yang digunakan sebagai jalan 16,16 Ha.

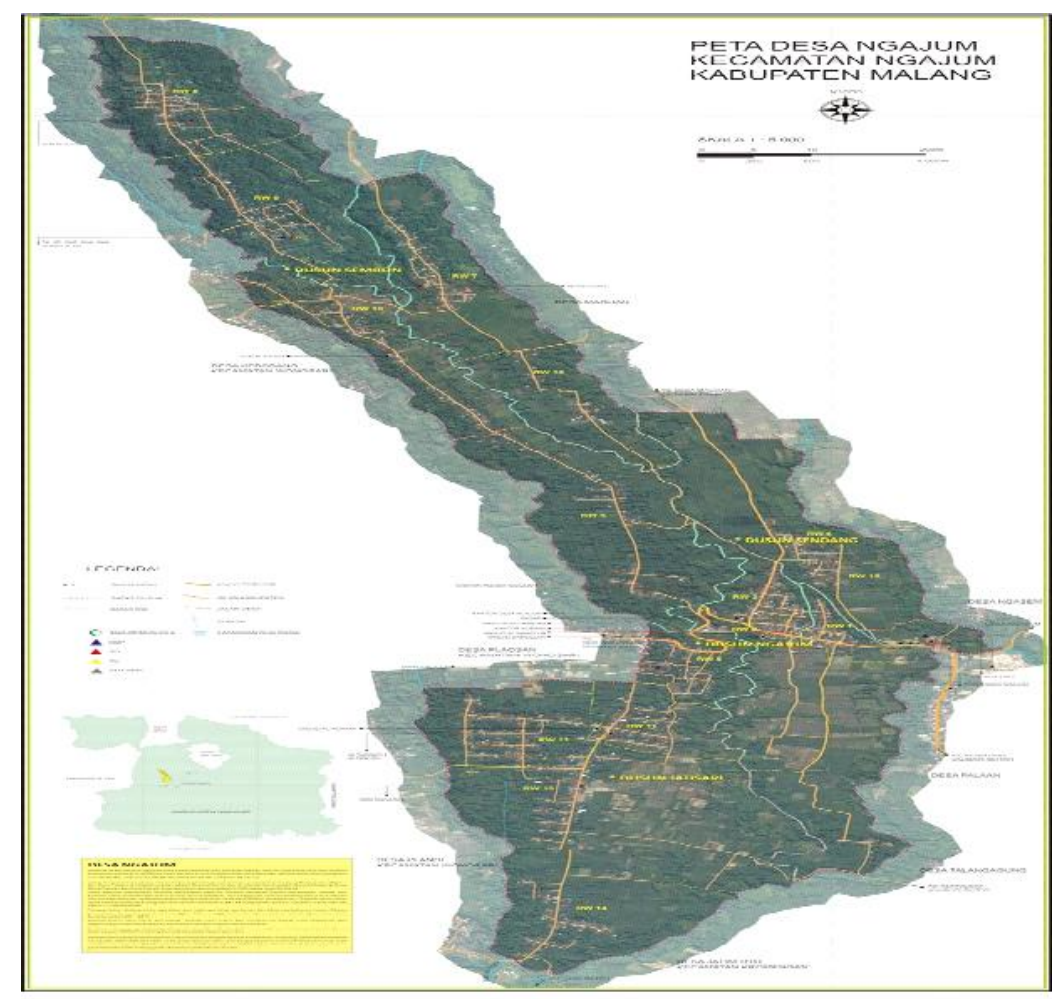

Gambar 2 Peta Wilayah Desa Ngajum

(Sumber: Pemerintah Desa Ngajum, 2017)

Desa Ngajum terletak di lahan dengan ketinggian 384 meter dpl, dengan mayoritas lahan berupa persawahan menyebabkan suhu rata-rata relatif rendah, yaitu $25^{\circ} \mathrm{C}$, dengan curah hujan 21,80 mm. Dengan jenis tanah yang relatif subur, dan sebagian besar berwarna hitam, maka tingkat erosi tanah di
Desa Ngajum dapat dikatakan rendah. Orbitasi Desa Ngajum terhadap Ibukota Kecamatan Ngajung adalah sejauh 0,50 Km, jarak dari Desa Ngajum menuju Ibu Kota Kabupaten Malang adalah sejauh $8 \mathrm{Km}$, yang menempuh waktu kendara selama 30 menit dengan kendaraan bermotor. Surabaya, 
sebagai ibukota Provinsi berjarak 135,00 $\mathrm{Km}$, yang membutuhkan waktu pencapaian sekitar 2-3 jam perjalanan dengan kendaraan bermotor.

Desa Ngajum berpenduduk sebesar 12.337 yang terdiri dari 6.145 warga berjenis kelamin laki-laki, dan 6.192 warga perempuan, terdiri atas 3.474 keluarga, yang menyebabkan angka kepadatan penduduk di Desa Ngajum berada pada angka 1.168 jiwa/km2. Jika ditinjau dari perspektif kesejahteraan, keluarga yang ada di Ngajum terkategorikan ke dalam Keluarga Prasejahtera sejumlah 809 KK, Keluarga Sejahtera tingkat 1 sejumlah 257 KK, Keluarga Sejahtera tingkat 2 sejumlah 788 KK, Keluarga Sejahtera tingkat 3 sejumlah 1.046 KK, dan Keluarga Sejahtera tingkat 3+ sejumlah $580 \mathrm{KK}$.

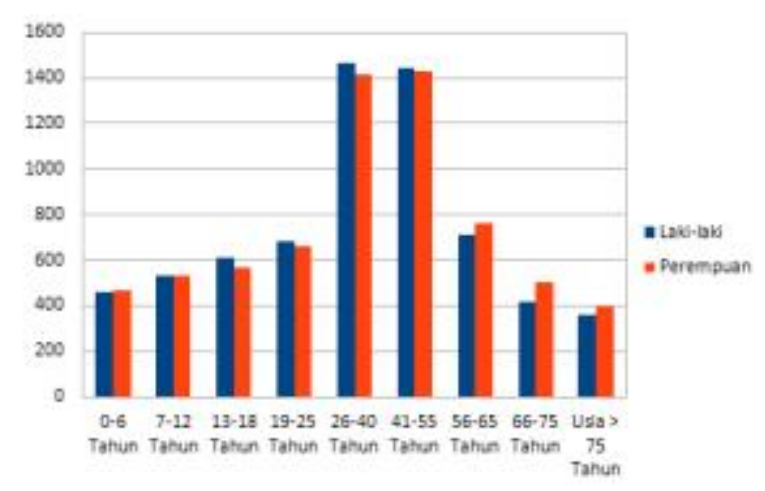

Gambar 3. Komposisi Usia Penduduk Desa Ngajum (Sumber: Pemerintah Desa Ngajum, 2020)
Komoditas tanaman pangan yang dihasilkan oleh Desa Ngajum adalah jenis tanaman jagung yang ditanam di lahan seluas 51,00 Ha dengan jumlah produksi mencapai 51,00 Ton/ha, cabe yang ditanam di lahan seluas 3,00 Ha dengan produksi 0,04 Ton/ha, kacang tanah yang ditanam di lahan seluas 3,00 Ha dengan hasil 1,00 Ton/ha, padi sawah yang ditanam di lahan seluas 394,00 Ha dengan panen 17,00 Ton/ha, dan tanaman ubi kayu yang ditanam di lahan seluas 15,00 Ha dan menghasilkan produksi 50,00 Ton/ha.

Untuk mencukupi pengairan tanaman pangan ini, Desa Ngajum dikaruniai aset sumber air bersih yang berlimpah. Tercatat ada 1.941 sumber mata air, 348 sumur gali, 18 sumur pompa, 271 depot isi ulang dan 896 yang berasal dari sumber lainnya. Kualitas air umumnya baik, dimana air tidak berbau, berwarna dan tidak berasa. 
Tabel 1. Hasil Analisis Potensi Wisata Desa Ngajum

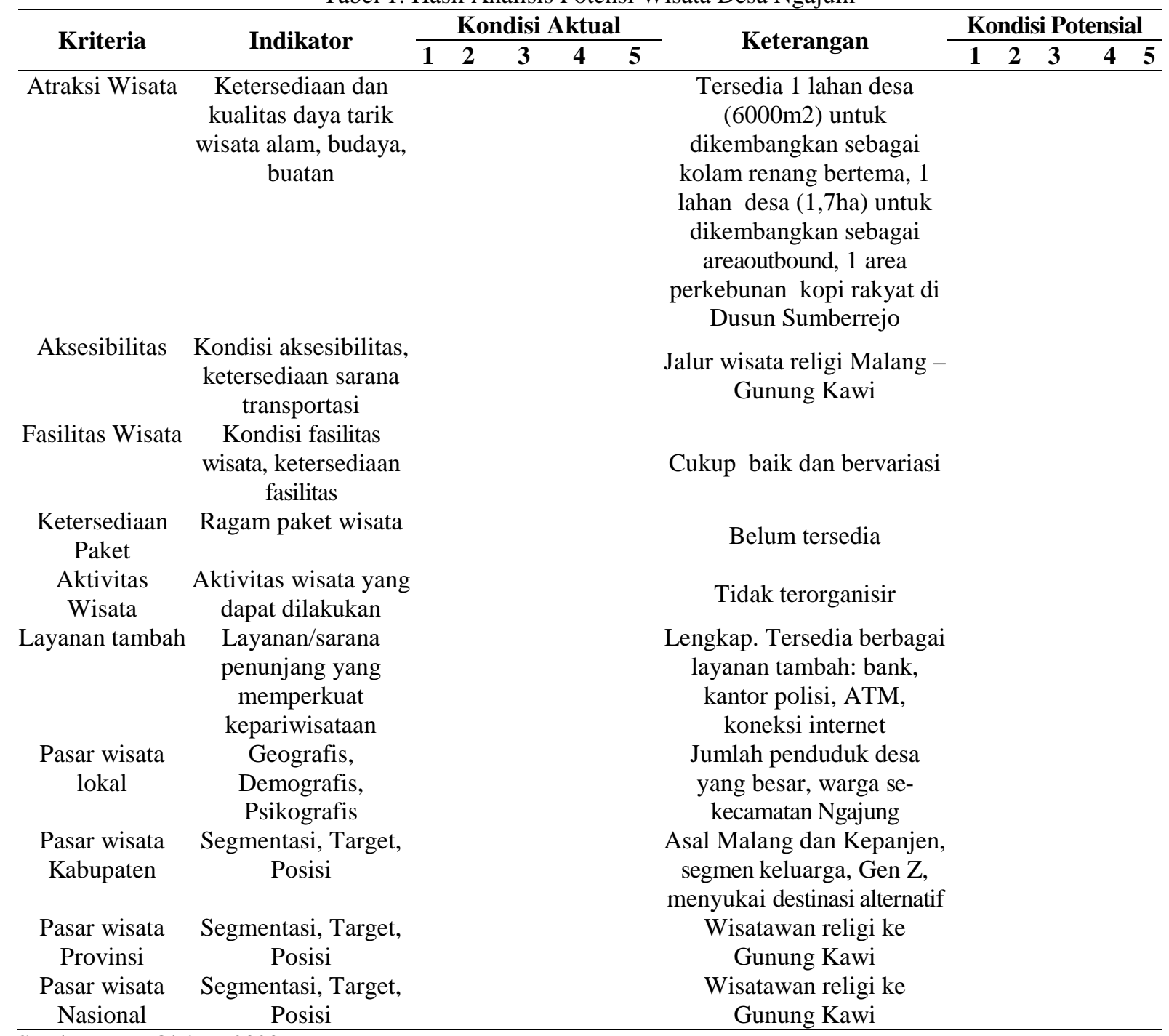

Sumber: Data Olahan, 2020

\section{Daya Tarik Wisata (attractions)}

Ketersediaan daya tarik wisata aktual di Desa Ngajum dapat dikatakan minimal. Setidaknya elemen yang paling signifikan dalam sistem pariwisata yang menjadi motivasi utama wisatawan di dalam melakukan perjalanan menuju Ngajum bisa dikatakan tidak eksis, selain tentunya untuk mengunjungi kawan dan keluarga (VFR). Tidak ada fitur lingkungan alam yang unik, yang tidak dimiliki oleh destinasi atau desa wisata lainnya. Namun terlepas dari kekurangan daya tarik wisata baik alami, budaya, maupun buatan, Desa Ngajum tetap memiliki sejumlah potensi yang berpeluang untuk menjadi daya tarik wisata jika dirancang, dikelola, dan dioperasikan dengan baik dan profesional.

Beberapa potensi daya tarik wisata yang teridentifikasi di Desa Ngajum adalah sebagai berikut: (1) Lahan desa A (Koordinat $\left.8^{\circ} 05^{\prime} 55.4^{\prime \prime L S} 112^{\circ} 32^{\prime} 38.0 " B T\right)$ seluas 6000 $\mathrm{m} 2$ merupakan satu lahan yang sudah dipersiapkan oleh pemerintah desa Ngajum untuk dikembangkan sebagai daya tarik wisata buatan berupa kolam renang pada tahun 2021. Pemilihan jenis daya tarik wisata buatan ini bukan tanpa pertimbangan. Terdapat beberapa pertimbangan mendasar terkait dengan penetapan jenis daya tarik wisata ini, diantaranya adalah karena ketersediaan sarana olahraga bagi masyarakat 
Ngajum yang terbatas. Dengan jumlah penduduk sebesar 12,337 jiwa harus diakui bahwa sarana olahraga yang dimiliki oleh Desa Ngajum amatlah terbatas. Selain alasan ini, ketiadaan sarana rekreasi masyarakat Desa Ngajum juga merupakan salah satu pertimbangan. Hal ini selaras dengan hasil dari kesepakatan deklarasi Manila (The World Tourism Conference, 1980) yang menyatakan bahwa pariwisata adalah kegiatan yang penting bagi kehidupan bangsa karena dampak langsungnya pada sektor sosial budaya, pendidikan dan ekonomi masyarakat nasional dan hubungan internasionalnya, juga bahwa akses terhadap hari libur dan perjalanan wisata adalah konsekuensi logis dan alami yang merupakan hak bagi semua manusia sebagaimana diakui sebagai aspek pemenuhan manusia oleh Deklarasi Universal Hak Asasi Manusia.

Selama ini masyarakat Desa Ngajum berekreasi ke luar wilayah Desa Ngajum, hal ini semata-mata karena ketiadaan sarana rekreasi yang dimiliki oleh Desa Ngajum. Dengan dikembangkannya lahan desa yang tidak produktif ini menjadi sebuah daya tarik wisata, maka tentu akan memberikan pilihan kepada warga masyarakat untuk dapat berekreasi tanpa harus keluar dari wilayah domisili mereka. Namun demikian, terdapat hal-hal penting yang patut dijadikan bahan pertimbangan bagi pemerintah desa di dalam mengembangkan lahan desa ini, yaitu (a) Pengembangan lahan desa sebagai kolam renang harus mengadopsi prinsip-prinsip wisata yang berkelanjutan sebagaimana yang sudah tertuang pada UU Nomor 10 Tahun 2009 Tentang Kepariwisataan, (b) pengelolaan daya tarik wisata ini selaras pula dengan peraturan Peraturan Menteri Kebudayaan Dan Pariwisata Nomor KM.18/HM.001/MKP/2011 Tentang Pedoman Program Nasional Pemberdayaan Masyarakat (PNPM) Mandiri Pariwisata, serta tentunya (c) jiwa dari pembangunan daya tarik wisata dilandasi oleh UndangUndang RI No 6 Tahun 2014 Tentang Desa.

Ke depannya, pengembangan daya tarik wisata ini tidak semata-mata hanya sebagai kolam renang biasa dimana pengunjung melakukan aktivitas wisata berenang saja, melainkan juga menjadi satu showcase bagi Desa Ngajum di dalam memasarkan produkproduk unggulan desa seperti hasil pertanian dan hasil perkebunan, sekaligus juga menjadi pusat informasi wisata yang terintegrasi dengan berbagai paket-paket aktivitas wisata yang tersedia di Desa Ngajum. Ini memiliki arti bahwa pengelolaan daya tarik wisata ini diarahkan untuk dapat dikelola oleh Bumdes dengan melibatkan peran Pokdarwis Ngajum dan diawasi pengelolaannya oleh Pemerintahan Desa Ngajum sebagai pemangku kepentingan utama masyarakat Desa Ngajum. Selain itu, desain daya tarik wisata ini patut pula mengakomodasi karakter wisatawan dan pengunjung milenial yang senantiasa terhubung dengan gawai dan media sosial, sehingga ketersediaan jaringan internet, serta penyediaan spot-spot swafoto adalah mutlak dibutuhkan untuk dapat mengakomodir kebutuhan pasar ini.

(2) Lahan desa B (Koordinat $8^{\circ} 06^{\prime} 43.3^{\prime \prime} L S$ $\left.112^{\circ} 32 ' 21.5^{\prime \prime} \mathrm{BT}\right)$. Lahan desa B dengan luas 1,7 hektar berpotensi untuk dikembangkan sebagai daya tarik wisata agrowisata dengan aktivitas ekowisata yang erat terkait dengan budaya pertanian dan perkebunan masyarakat. Dengan setting perbukitan rendah dan dikelilingi oleh suasana alami persawahan, lahan ini berpotensi untuk dikembangkan sebagai area aktivitas ekowisata tanpa mengubah peruntukan awal dari lahan ini, yaitu sebagai area pertanian dan perkebunan. Aktivitas penjelajahan alam, berkemah, observasi alam, trekking, fotografi, pembelajaran tentang pertanian, pembelajaran tentang berkebun, dan pembelajaran tentang peternakan masyarakat adalah beberapa aktivitas wisata yang cocok dikembangkan di area ini. Pengembangan terhadap fasilitas makan minum yang memadupadankan lansekap alam persawahan juga layak dipertimbangkan untuk pengembangan di masa yang akan datang.

(3) Perkebunan Kopi Masyarakat di Dusun Sumberrejo (Koordinat $\quad 8^{\circ} 03^{\prime} 01.9^{\prime \prime} \mathrm{LS}$ 
112³1'09.0"BT). Desa Ngajum memiliki area perkebunan kopi dan nangka yang dimiliki dan dikelola oleh masyarakat. Tanaman kopi yang tumbuh di perkebunan kopi masyarakat ini adalah berjenis robusta $(80 \%)$ dan liberika $(20 \%)$. Pada area ini berpotensi untuk dikembangkan daya tarik wisata perkebunan kopi masyarakat dengan pengembangan pada aktivitas wisata yang terkait dengan proses budidaya kopi, mulai dari pembelajaran tentang varietas jenis biji kopi, pembibitan, pemilihan lahan, proses penanaman, perawatan yang didalamnya meliputi: penyulaman, pemupukan, pemangkasan, dan penyiangan gulma, juga tentang pengantisipasian hama, serta pemanenan/pemetikan. Selanjutnya wisatawan diarahkan untuk juga mempelajari proses penyiapan hidangan kopi mulai dari fase pemanggangan biji kopi hingga ke penyajian ke dalam secangkir kopi. Namun demikian, dikarenakan lokasi perkebunan kopi ini tidak cukup strategis, maka diperlukan pengembangan dan pemasaran dengan sinergitas daya tarik wisata pada lahan desa $\mathrm{A}$, yang memiliki nilai lokasi strategis. Jenis agrowisata yang terkait dengan perkebunan kopi sudah cukup banyak diterapkan, diantaranya dapat dijumpai di area perkebunan kopi yang dikelola oleh PTPN (Dwi Ginanti, 2020), dikelola oleh masyarakat setempat (Indrasari, 2020), maupun beberapa contoh wisata perkebunan kopi di luar negeri yang dikaji oleh peneliti asing (Candelo et al., 2019; Wang et al., 2019).

(4) Pabrik Susu Greenfield (Koordinat 805'57.1"LS 112³2'59.2"BT). Pabrik pengolahan susu Greenfield adalah salah satu potensi yang dapat dikembangkan sebagai daya tarik wisata factory tour. Walau secara administratif tidak terletak langsung di wilayah Desa Ngajum, namun Pabrik Susu Greenfield tetap berpeluang untuk dijadikan potensi wisata yang pengelolaannya di bawah Bumdes dan Pokdarwis Desa Ngajum. Hal ini tentunya membutuhkan kolaborasi lebih lanjut antara pihak Greenfield dengan perwakilan dari Desa Ngajum yang dalam hal ini Bumdes dan Pokdarwis. Jenis aktivitas wisata berpotensi dapat dilakukan di Pabrik Susu Greenfield adalah jenis aktivitas Factory Tour. Berwisata dan mengunjungi pabrik telah menjadi salah satu kegiatan rekreasi utama dan favorit wisatawan domestik (Lee, 2015; Lin, 2020). Dimana menurut Lee, terdapat 7 (tujuh) dimensi kegiatan kunjungan pabrik yang berpotensi dapat ditawarkan, yaitu: (a) fasilitas penginapan dan makanan; (b) aksesibilitas internal; (c) atraksi yang dekat dengan pabrik; (d) aksesibilitas eksternal; (e) penyediaan sistem keselamatan/darurat; (f) daya tarik di pabrik; dan (g) layanan informasi. Untuk tahapan awal kolaborasi antara Pabrik Greenfield dengan Bumdes/Pokdarwis Desa Ngajum, jenis aktivitas wisata yang menawarkan atraksi di pabrik, penyediaan informasi, dan dikombinasikan dengan penyediaan minuman dari produk susu dapat dilakukan. Sementara jenis-jenis dimensi lain dari wisata pabrik dapat menyusul seiring dengan berjalannya waktu dan kesiapan SDM dari kedua belah pihak.

(5) Padepokan/Petilasan Soerjo Alam (Koordinat $8^{\circ} 03^{\prime} 43.7^{\prime \prime L S} \quad 112^{\circ} 31^{\prime} 15.9^{\prime \prime} \mathrm{BT}$ ). Padepokan Soerjo Alam yang berlatarbelakangkan sejarah kerajaan mataram memiliki karakter tersendiri sebagai daya tarik wisata minat khusus. Padepokan ini jika ditinjau dari perspektif pariwisata merupakan satu daya tarik yang mampu mendatangkan wisatawan spiritual/religi yang merupakan salah satu jenis niche market, dalam tinjauan pasar wisata. Beberapa contoh dari pengembangan wisata spiritual telah coba digali oleh para ahli (Hodge, 2006; Parsons et al., 2020; Wulandari \& Adikampana, 2018). Figur sentral dari padepokan Soerjo Alam adalah Eyang Soerjo Alam, seorang tokoh masyarakat yang telah meninggal ratusan tahun silam, yang diyakini merupakan tokoh utama yang membuka lahan Desa Ngajum untuk pertama kalinya. Tokoh ini sekaligus juga mewartakan ajaran Islam dalam bentuk intisari Islam, pada periode pelarian yang bersangkutan di masa Perang Diponegoro (1825-1830). Eyang Soerjo Alam ini juga 
dikenal dengan sebutan Pangeran Diponegoro, dikarenakan selain dari yang dipahami oleh masyarakat umum - bagi praktisi spiritualis Jawa, Diponegoro adalah sebuah gelar kehormatan, yang dimiliki oleh orang-orang tertentu saja dimasa peperangan Jawa, dan Eyang Soerjo Alam ini adalah salah satu dari Diponegoro, layaknya seperti Pangeran Diponegoro yang dikenal oleh masyarakat pada umumnya.

(6) Suasana alami pedesaan tradisional dengan lansekap sawah. Desa Ngajum dikelilingi oleh lansekap alami persawahan (lebih dari $50 \%$ area desa) dengan suasana desa tradisional yang menarik. Suasana persawahan ini terbukti berpotensi menjadi daya tarik wisata sebagaimana lokasi persawahan di Tegalalang (Sulistyawati, 2010), Jatiluwih (Diyah \& Widari, 2015; Prasiasa \& Damanik, 2010), Pujonkidul (Ira \& Muhamad, 2020) yang kesemua tempat ini memiliki daya tarik wisata utama berupa setting alam persawahan. Terdapat beberapa titik yang berpeluang untuk dikembangkan sebagai titik-titik lokasi swafoto yang dapat menunjang daya tarik lainnya yang dimiliki oleh Desa Ngajum. Yang juga patut diperhatikan di dalam pembangunan spot swafoto ini adalah penggunaan bahan-bahan yang ramah lingkungan dan mudah ditemukan di daerah sekitar, yang dipadukan dengan kreativitas sehingga mampu menghasilkan spot foto yang menarik dan instagrammable.

(7) Kegiatan ritual kebudayaan masyarakat. Tradisi 1 Suro, berawal dari tradisi lingkungan Keraton Jawa (Yogyakarta dan Surakarta) yang pada dasarnya memiliki makna perayaan malam suci dan awal dari bulan yang penuh rahmat (Giri, 2010; Sholikhin, 2010). Dimana pada malam ini masyarakat setempat akan mendekatkan diri kepada Tuhan YME dengan perilaku membersihkan diri melawan segala godaan hawa nafsu, dengan menjalankan tirakat dan lelaku atau perenungan diri. Dalam konteks masyarakat Desa Ngajum, perayaan ini berlangsung selama 2 (dua) hari, dimana pada hari pertama dilakukan upacara pemandian keris dan pusaka yang dimiliki oleh tetua masyarakat, dan dilanjutkan dengan pelaksanaan upacara adat pada hari berikutnya, yang menyerupai upacara Grebek Suro yang dapat ditemukan di Jogja dan Solo.

\section{Aksesibilitas (accessibilities)}

Kondisi aksesibilitas di Desa Ngajum dapat dikatakan dalam keadaan yang baik. Ruas jalan utama di Desa Ngajum yang menghubungkan antara Kota Kepanjen dan Kota Malang menuju kawasan wisata religi Gunung Kawi yang terletak $14 \mathrm{~km}$ dari pusat Desa Ngajum beraspal hotmix yang mulus. Hal ini tentunya menjadi kekuatan dari potensi wisata Desa Ngajum. Letak Desa Ngajum yang berada pada perlintasan jalur wisata religi Gunung Kawi juga menjadi sebuah potensi bagi aktivitas wisata di Desa Ngajum sebagai transit point dari para pilgrimage Gunung Kawi. Transit point atau titik perhentian sementara dalam satu rangkaian perjalanan wisata adalah penting, sebagaimana hal ini juga menjadi topik yang menarik minat para peneliti (Hwang et al., 2006; Lohmann et al., 2009; Tang et al., 2017). Selain kondisi jalan yang baik dan kelas jalan yang memadai, transportasi umum berwarna biru laut dari Kepanjen menuju Gunung Kawi juga melintasi Desa Ngajum setiap harinya. Ketersediaan lahan parkir yang luas di Lahan Desa A, juga merupakan satu aset bagi pengembangan wisata Desa Ngajum. Untuk mengunjungi Desa Ngajum dari Terminal Talang Agung Kepanjen, wisatawan cukup mengarah ke Jalan Molek I sejauh 300 meter, dan selanjutnya belok kanan ke Jalan Raya Gunung Kawi untuk kemudian mengikuti jalur utama sejauh 4,6 kilometer dan sampai ke Kantor Desa Ngajum. 


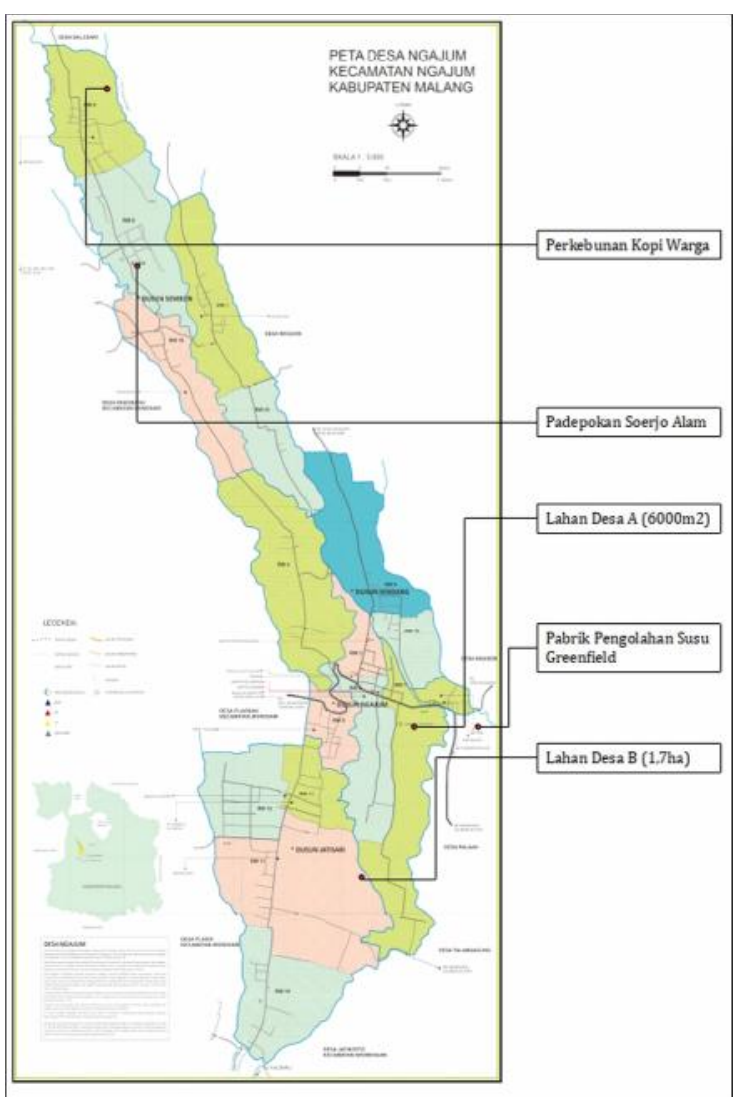

Gambar 4. Potensi Daya Tarik Wisata Desa Ngajum Sumber: Pemerintah Desa Ngajum, 2017 dan Data Olahan, 2020

\section{Aktivitas Wisata (activities)}

Saat ini harus diakui bahwa keberadaan aktivitas wisata di Desa Ngajum masih minimal. Tidak ditemukan wisatawan yang melakukan kunjungan ke Desa Ngajum dengan motivasi berwisata. Namun, seiring dengan pengembangan daya tarik wisata yang sedang direncanakan oleh Pemerintah Desa Ngajum, maka secara logis aktivitas wisata akan bermunculan. Terlebih lagi pemasaran paket-paket wisata yang terintegrasi, maka potensi pemerataan aktivitas wisata di Desa Ngajum akan berpeluang lebih merata dan tidak terkonsentrasi pada satu titik daya tarik wisata.

\section{Fasilitas Wisata (amenities)}

Fasilitas wisata di Desa Ngajum umumnya didominasi oleh jenis fasilitas yang diperuntukkan bagi masyarakat sekitar. Namun demikian sudah terdapat sejumlah fasilitas akomodasi di Desa Ngajum, walau tidak dapat dipungkiri bahwa mayoritas fasilitas penginapan lebih terkonsentrasi di desa tetangga Wonosari, yang memang terletak di lokasi yang sama dengan destinasi wisata religi Gunung Kawi. Namun demikian, fasilitas makan minum dan fasilitas layanan serta perdagangan ritel tersedia dalam jumlah yang cukup memadai di Desa Ngajum. Fenomena kurangnya fasilitas penginapan ini juga memberikan peluang bagi Bumdes/Pokdarwis Ngajum untuk menyediakan fasilitas penginapan sederhana yang menjadi satu lokasi dengan pengembangan daya tarik wisata wahana tirta yang sudah direncanakan di lahan desa A.

\section{Ketersediaan Paket (available packages)}

Saat ini belum tersedia paket-paket wisata yang menunjang kepariwisataan di Ngajum. Namun demikian, bukan berarti tidak terdapat potensi pada komponen ini. Seiring dengan berkembangnya daya tarik wisata dan aktivitas wisata di Desa Ngajum, maka turut dan akan berkembang pula berbagai paket wisata di Desa Ngajum. Beberapa paket-paket wisata yang berpotensi dipasarkan kepada wisatawan baik secara langsung (direct) maupun tidak langsung (indirect) melalui kanal pemasaran biro perjalanan wisata ataupun OTA (online travel agencies) diantaranya adalah: paket wisata tiket masuk wahana renang yang terintegrasi dengan produk unggulan Desa Ngajum seperti hasil pertanian, hasil perkebunan, hasil peternakan, ataupun produk kreatif masyarakat setempat seperti jajan pasar, minuman kopi, dan lain sebagainya. Paket wisata lain yang memungkinkan dipasarkan pula adalah paketpaket agrowisata, paket-paket ekowisata, paket factory tour, dan juga paket wisata spiritual. Bahkan tidak menutup kemungkinan bagi Bumdes/Pokdarwis memasarkan paket-paket wisata yang terkait dengan destinasi wisata yang tidak terdapat di Desa Ngajum, seperti Paket Wisata Religi ke Gunung Kawi. Sebaiknya upaya pemasaran paket-paket wisata ini ke depannya perlu dikelola dalam satu pintu di bawah kendali dan pengelolaan dari Bumdes/Pokdarwis Desa Ngajum. Hal ini untuk memaksimalkan kepuasan pelanggan dan pengawasan operasional dari paket-paket wisata yang dipasarkan. 
Layanan tambah (ancillary services)

Layanan tambah adalah komponen produk wisata yang memiliki nilai tinggi yang dimiliki oleh Desa Ngajum. Lokasi Desa Ngajum yang berdekatan dengan Ibukota Kecamatan, membuat ketersediaan layanan tambah ini signifikan. Hal ini bisa terlihat dari ketersediaan berbagai pilihan layanan tambah seperti; bank, kantor pos, rumah sakit, jaringan telekomunikasi yang baik, kantor polisi (Polsek Ngajum), sarana peribadatan, dan ketersediaan jaringan perdagangan waralaba ritel. Kekuatan layanan tambah ini diharapkan dapat menjadi elemen penguat bagi keseluruhan nilai Desa Ngajum ditinjau dari perspektif produk wisata.

Tabel 2. Analisis Potensi Pasar Wisata Desa Ngajum

\begin{tabular}{|c|c|c|c|c|c|}
\hline \multirow{2}{*}{ Produk Wisata } & \multicolumn{3}{|c|}{ Segmentasi } & \multirow{2}{*}{ Target } & \multirow{2}{*}{ Posisi } \\
\hline & Geografis & Demografis & $\overline{\text { Psikografis/Behaviour }}$ & & \\
\hline $\begin{array}{c}\text { Wahana Tirta (Lahan } \\
\text { Desa A) }\end{array}$ & $\begin{array}{l}\text { Warga Desa } \\
\text { Ngajum, } \\
\text { Warga se- } \\
\text { Kecamatan } \\
\text { Ngajum }\end{array}$ & $\begin{array}{l}\text { Semua usia, pria } \\
\text { \&wanita, } \\
\text { incomemenengah } \\
\text { ke bawah, tingkat } \\
\text { pendidikan } \\
\text { menengah }\end{array}$ & Keluarga, milenials & $\begin{array}{c}\text { Umum } \\
\text { \&wisatawan } \\
\text { transit (ke Gunung } \\
\text { Kawi) }\end{array}$ & $\begin{array}{l}\text { Satu-satunya } \\
\text { wahana tirta di } \\
\text { Kecamatan } \\
\text { Ngajum }\end{array}$ \\
\hline $\begin{array}{c}\text { Ekowisata/Agrowisata } \\
\text { (Lahan Desa B) }\end{array}$ & $\begin{array}{l}\text { Kota } \\
\text { Malang, } \\
\text { Kepanjen, } \\
\text { Blitar, } \\
\text { Surabaya }\end{array}$ & $\begin{array}{l}\text { Usia pelajar, pria } \\
\text { \&wanita, } \\
\text { incomemenengah, } \\
\text { tingkat pendidikan } \\
\text { dasar-menengah }\end{array}$ & $\begin{array}{l}\text { Menyukai aktivitas di } \\
\text { alam, terkait dengan } \\
\text { pembelajaran (wisata } \\
\text { edukasi) }\end{array}$ & $\begin{array}{c}\text { Ecotourists, siswa } \\
\text { sekolah (SD- } \\
\text { SMA) }\end{array}$ & $\begin{array}{c}\text { Pengalaman } \\
\text { pembelajaran } \\
\text { alam di setting } \\
\text { alami }\end{array}$ \\
\hline Perkebunan Kopi & $\begin{array}{l}\text { Kota } \\
\text { Malang, } \\
\text { Kepanjen, } \\
\text { Blitar, } \\
\text { Surabaya }\end{array}$ & $\begin{array}{l}\text { Usia produktif- } \\
\text { lansia, pria } \\
\text { \&wanita, } \\
\text { incomemenengah } \\
\text { ke atas, tingkat } \\
\text { pendidikan } \\
\text { menengah - tinggi }\end{array}$ & $\begin{array}{l}\text { Pemerhati, penikmat, } \\
\text { dan loyalis kopi }\end{array}$ & $\begin{array}{l}\text { Niche } \\
\text { Market(Penggemar } \\
\text { Kopi) }\end{array}$ & $\begin{array}{l}\text { Pengalaman } \\
\text { asli kopi dari } \\
\text { awal hingga } \\
\text { kopi terhidang } \\
\text { di cangkir }\end{array}$ \\
\hline $\begin{array}{l}\text { Factory Tourdi Pabrik } \\
\text { Susu Greenfield }\end{array}$ & $\begin{array}{c}\text { Kota } \\
\text { Malang, } \\
\text { Kepanjen, } \\
\text { Blitar, } \\
\text { Surabaya }\end{array}$ & $\begin{array}{l}\text { Usia pelajar, pria } \\
\text { \&wanita, } \\
\text { incomemenengah, } \\
\text { tingkat pendidikan } \\
\text { dasar-tinggi }\end{array}$ & $\begin{array}{c}\text { Wisatawan } \\
\text { berkelompok (group), } \\
\text { terkait dengan } \\
\text { pembelajaran(wisata } \\
\text { edukasi) }\end{array}$ & $\begin{array}{c}\text { Siswa Sekolah } \\
\text { (TK-Universitas), } \\
\text { Perkumpulan } \\
\text { Komunitas }\end{array}$ & $\begin{array}{c}\text { Satu-satunya } \\
\text { tour ke pabrik } \\
\text { susu di Jawa } \\
\text { Timur }\end{array}$ \\
\hline $\begin{array}{c}\text { Padepokan Soerjo } \\
\text { Alam }\end{array}$ & $\begin{array}{c}\text { Nasional, } \\
\text { Internasional }\end{array}$ & $\begin{array}{l}\text { Usia produktif- } \\
\text { lansia, pria } \\
\text { \&wanita, } \\
\text { incomemenengah } \\
\text { ke atas, tingkat } \\
\text { pendidikan } \\
\text { menengah }\end{array}$ & $\begin{array}{l}\text { Milenial \&Gen } X \text {, } \\
\text { pemerhati dan praktisi } \\
\text { spiritual }\end{array}$ & $\begin{array}{c}\text { Niche Market } \\
\text { (Wisata Spiritual / } \\
\text { Spiritual Journey) }\end{array}$ & $\begin{array}{l}\text { Nilai sejarah } \\
\text { dan budaya } \\
\text { yang tinggi } \\
\text { bagi pemerhati } \\
\text { aliran spiritual }\end{array}$ \\
\hline $\begin{array}{c}\text { Swafoto di lansekap } \\
\text { persawahan }\end{array}$ & $\begin{array}{l}\text { Kota } \\
\text { Malang, } \\
\text { Kepanjen, } \\
\text { Blitar, } \\
\text { Surabaya }\end{array}$ & $\begin{array}{l}\text { Semua usia, pria } \\
\& \text { wanita, } \\
\text { incomemenengah } \\
\text { ke bawah, tingkat } \\
\text { pendidikan } \\
\text { menengah }\end{array}$ & Milenial, Gen Z & $\begin{array}{c}\text { Umum dan } \\
\text { wisatawan transit } \\
\text { ke/dari Gunung } \\
\text { Kawi }\end{array}$ & $\begin{array}{c}\text { Side } \\
\text { attractionsbagi } \\
\text { daya tarik } \\
\text { wisata lainnya }\end{array}$ \\
\hline $\begin{array}{c}\text { Ritual Kebudayaan } \\
\text { Masyarakat }\end{array}$ & $\begin{array}{l}\text { Nasional, } \\
\text { Internasional }\end{array}$ & $\begin{array}{l}\text { Usia produktif, } \\
\text { pria \&wanita, } \\
\text { incomemenengah } \\
\text { - atas, pendidikan: } \\
\text { SMA - Tinggi }\end{array}$ & $\begin{array}{l}\text { Menggemari ritual } \\
\text { budaya asli/otentik }\end{array}$ & $\begin{array}{c}\text { Niche Market } \\
\text { (Kebudayaan dan } \\
\text { Tradisi } \\
\text { Masyarakat) }\end{array}$ & $\begin{array}{c}\text { Event } \\
\text { kebudayaan } \\
\text { tahunan yang } \\
\text { potensial }\end{array}$ \\
\hline
\end{tabular}

Sumber: Data Olahan, 2020 


\section{SIMPULAN}

Kesimpulan yang dapat ditarik adalah bahwa secara umum Desa Ngajum memiliki potensi wisata yang masih belum tergali dan teroptimalkan dengan baik. Potensi wisata yang terdapat di Desa Ngajum terdapat pada kedua sisi, baik penawaran maupun dari sisi permintaan pariwisata. Kekurangan yang terdapat pada sisi penawaran, khususnya pada komponen daya tarik wisata (attractions) dan komponen ketersediaan paket wisata (available packages) akan dapat teratasi dengan dikembangkannya atraksi wisata buatan berupa kolam renang pada lahan desa di titik koordinat $8^{\circ} 05^{\prime} 55.4^{\prime \prime L S} 112^{\circ} 32 ' 38.0 " B T$ seluas $6000 \mathrm{~m}^{2}$ yang memang sudah direncanakan bahkan sebelum studi ini dilakukan. Dengan catatan bahwa pembangunan fisik wahana tirta dilakukan dengan mengoptimalkan pandangan ke lansekap persawahan yang mengelilingi area lahan sebagai daya tarik penunjang, dan dikembangkan dengan prinsip ramah lingkungan sekaligus mengangkat nilai budaya dan manfaat masyarakat setempat. Selanjutnya, lahan desa pada koordinat $8^{\circ} 06^{\prime} 43.3^{\prime \prime} L S$ $112^{\circ} 32 ' 21.5 " B T$ seluas 1,7 hektar dapat dimanfaatkan sebagai area aktivitas ekowisata dan agrowisata, sementara perkebunan kopi yang dimiliki oleh masyarakat desa pada koordinat $8^{\circ} 03^{\prime} 01.9^{\prime \prime} \mathrm{LS} 112^{\circ} 31^{\prime} 09.0^{\prime \prime} \mathrm{BT}$ dapat pula dimanfaatkan sebagai lokasi aktivitas ekowisata/agrowisata. Potensi atraksi wisata yang juga perlu dikembangkan adalah Pabrik Susu Greenfield yang berpotensi menjadi lokasi factory tour. Semua potensi ini tentu harus dirancang dan dikembangkan secara bertahap agar mendapatkan hasil yang optimal bagi masyarakat desa Ngajum. Oleh karenanya pengelolaan atraksi potensial ini perlu memanfaatkan peranan daripada Bumdes dan Pokdarwis Desa Ngajum sebagai aktor utama dari kepariwisataan di Desa Ngajum. Komponen fasilitas wisata (amenities) sudah cukup baik, sedangkan aktivitas wisata (activities) tentunya akan selaras dengan pengembangan atraksi wisata. Komponen aksesibilitas (accessibilities) dan layanan tambah (ancillary services) merupakan komponen produk wisata yang sudah dapat dikategorikan dalam kondisi baik.
Pada sisi permintaan wisata, Desa Ngajum memiliki potensi besar bonus demografi jumlah penduduk. Jumlah penduduk sebesar 12.337 yang terdiri atas 3.474 keluarga selama ini melakukan aktivitas rekreasi di luar wilayah Desa Ngajum. Ke depannya, masyarakat ini yang diharapkan menjadi pasar utama bagi atraksi wisata yang dimiliki oleh Desa Ngajum. Potensi lainnya adalah jumlah warga Kecamatan Ngajung yang besar, yaitu 49.504 jiwa, artinya terdapat 37.167 warga sekecamatan di luar Desa Ngajum yang berpotensi menjadi pengunjung (excursionists) ke Desa Ngajum. Letak Desa Ngajum yang cukup strategis pada perlintasan jalur wisata religi Gunung Kawi juga merupakan potensi yang tidak bisa dikesampingkan. Jalur wisata religi yang mampu mendatangkan ratusan ribu pengunjung per tahun ini tentu juga berpotensi memberikan kontribusi wisatawan yang transit pada saat mereka sedang menuju ke atau dari destinasi utama mereka Gunung Kawi.

Sehubungan dengan kesimpulan ini, maka penelitian lanjutan yang perlu dilakukan adalah pengkajian strategi pengembangan produk wisata di Desa Ngajum dengan mengidentifikasi aspek kekuatan, kelemahan, peluang dan ancaman yang dimiliki oleh Desa Ngajum dan berbagai aspek terkait lainnya. Kajian lanjutan terkait dengan pasar wisata juga dibutuhkan. Pada akhirnya perlu pula dilakukan suatu kajian rencana tapak terhadap tiga daya tarik wisata potensial tersebut, yang diawali dengan studi kelayakan tiap-tiap daya tarik wisata yang hendak dikembangkan.

\section{UCAPAN TERIMA KASIH}

Ucapan terima kasih atas partisipasi masyarakat Desa Ngajum, khususnya Bapak Kades Setyo Budi dan Bapak Taofiq Hidayah yang turut serta berkontribusi atas selesainya kajian ini.

\section{REFERENSI}

Alghizzawi, M. (2019). A survey of the role of social media platforms in viral marketing: The influence of eWOM. International Journal of Information Technology, 3(2), 54-60. 
Andreopoulou, Z., Tsekouropoulos, G., Koliouska, C., \& Koutroumanidis, T. (2014). Internet marketing for sustainable development and rural tourism. International Journal of Business Information Systems, 16(4), 446.

https://doi.org/10.1504/IJBIS.2014.0639 $\underline{31}$

Arcana, K. T. P., \& Wiweka, K. (2015). The Potential Development of Community Based Tourism at Ambengan Village, Buleleng Regency, Bali. Journal of Business on Hospitality and Tourism, 1(1), 11.

https://doi.org/10.22334/jbhost.v1i1.14

Ashar, A., \& Agustang, A. (2020). Dampak Sosial Dana Desa Dalam Kesejahteraan Masyarakat Di Desa Kalola, Kecamatan Maniangpajo, Kabupaten Wajo. Jurnal Sosialisasi, 7(2), 19-25.

Asmoro, A. Y., Aly, M. N., \& Pratama, H. F. (2020). Identifikasi Service Blueprint di Desa Wisata Kebontunggul (Lembah Mbencirang), Kecamatan Gondang, Kabupaten Mojokerto. Inovbiz: Jurnal Inovasi Bisnis, 8(2), 1-13.

Asmoro, A. Y., \& Aziz, M. (2020). Potensi Pengembangan Setigi sebagai Destinasi Wisata. JMK (Jurnal Manajemen Dan Kewirausahaan), 5(3), 228. https://doi.org/10.32503/jmk.v5i3.1136

Asmoro, A. Y., \& Yusrizal, F. (2020).

Potensi Pola Perjalanan Ekowisata Jawa Timur Pasca Pandemi Covid-19. Jurnal IPTA (Industri Perjalanan Wisata), $8(2), 1-22$.

Asmoro, A. Y., Yusrizal, F., \& Saputra, I. (2020). Pariwisata Berbasis Masyarakat di Desa Sekapuk - sebuah Participatory Action Research. Jurnal Pendidikan Dan Pemberdayaan Masyarakat, 7(2), $1-19$.
Atmoko, T. P. H. (2014). Strategi Pengembangan Potensi Desa Wisata Brajan Kabupaten Sleman. Jurnal Media Wisata, 12(2), 146-154. https://amptajurnal.ac.id/index.php/MW S/article/view/87

Ayu, I. G., Suryawardani, O., Wiranatha, A. S., \& Petr, C. (2014). Destination Marketing Strategy in Bali Through Optimizing the Potential of Local Products. Journal of Tourism, 1(1), 3549.

https://doi.org/10.24922/eot.v1i1.19302

Bell, S., Tyrv Äinen, L., Siev Änen, T., Pr

Öbstl, U., \& Simpson, M. (2007).

Outdoor Recreation and Nature Tourism: A European Perspective. Living Reviews in Landscape Research, 1(2), 2. https://doi.org/10.12942/lrlr$\underline{\text { 2007-2 }}$

Bethapudi, A. (2015). Role of ICT in promoting a rural tourism product. Journal of Tourism and Hospitality, 4(3), 154.

http://www.omicsgroup.org/journals/rol e-of-ict-in-promoting-a-rural-tourismproduct-2167-02691000154.php?aid $=57960$

Briedenhann, J., \& Wickens, E. (2004). Tourism routes as a tool for the economic development of rural areasvibrant hope or impossible dream? Tourism Management, 25(1), 71-79. https://doi.org/10.1016/S0261$\underline{\text { 5177(03)00063-3 }}$

Buckles, D. (2019). Participatory action research: Theory and methods for engaged inquiry. Journals.Sagepub.Com. https://doi.org/10.4324/9781351033268

Buhalis, D. (2000). Marketing the competitive destination of the future. Tourism Management, 21(1), 97-116. 
https://doi.org/10.1016/S02615177(99)00095-3

Butler, R. W. (2019). Tourism carrying capacity research: a perspective article. Tourism Review, 75(1), 207-211. https://doi.org/10.1108/TR-05-2019$\underline{0194}$

Cahyono, H., Aziz, N. L. L., Nurhasim, M., Rahman, A. R., \& Zuhro, R. Si. (2020). Pengelolaan Dana Desa Studi dari Sisi Demokratis dan Kapasitas Pemerintahan Desa. In Proposal SIMLITAMAS. https://www.kemenkeu.go.id/media/674 9/buku-pintar-dana-desa.pdf

Candelo, E., Casalegno, C., Civera, C., \& Büchi, G. (2019). A ticket to coffee: Stakeholder view and theoretical framework of coffee tourism benefits. Tourism Analysis, 24(3), 329-340.

Carlsen, J. (1999). A systems approach to island tourism destination management. Systems Research and Behavioral Science, 16(4), 321-327. https://doi.org/10.1002/(SICI)10991743(199907/08)16:4<321::AIDSRES255>3.0.CO;2-5

Chahal, H., \& Devi, A. (2015). Destination Attributes and Destination Image Relationship in Volatile Tourist Destination: Role of Perceived Risk. Metamorphosis: A Journal of Management Research, 14(2), 1-19. https://doi.org/10.1177/0972622520150 $\underline{203}$

CNN Indonesia. (2020). 479 Desa Wisata Jatim Dibuka, Protokol Kesehatan Diperketat. https://www.cnnindonesia.com/nasional /20200706064403-20-521181/479-desawisata-jatim-dibuka-protokolkesehatan-diperketat

Cooper, C. (1998). Tourism : principles and practice (2nd ed.).
Costa, A. P. (2020). Computer Supported Qualitative Research (A. P. Costa, L. P. Reis, \& A. Moreira (eds.); Vol. 1068, Issue September 2019). Springer International Publishing. https://doi.org/10.1007/978-3-030$\underline{31787-4}$

Costa, C. (2019). Tourism planning: a perspective paper. Tourism Review, 75(1), 198-202. https://doi.org/10.1108/TR-09-2019$\underline{0394}$

Costa, C. (2020). A Model for the Development of Innovative Tourism Products : From Service to A Model for the Development of Innovative Tourism Products : from Service to Transformation. May. https://doi.org/10.3390/su12114362

Daher, I. S. (2016). Pemberdayaan masyarakat melalui koperasi kasongan usaha bersama (kub) di desa wisata kasongan bantul yogyakarta. Jurnal Elektronik Mahasiswa Pend. Luar Sekolah - S1, 5(4), 1-12.

Diyah, D. A., \& Widari, S. (2015). Perkembangan desa wisata jatiluwih setelah unesco menetapkan subaknya sebagai bagian dari warisan budaya dunia. In jumpa (Vol. 2).

https://ojs.unud.ac.id/index.php/JAT/arti cle/download/6078/4572

Dwi Ginanti, L. (2020). Perkembangan PTPN IX Agrowisata Kampoeng Kopi Banaran di Kabupaten Semarang Tahun 2002-2017. In ejournal3.undip.ac.id (Vol. 1, Issue 1).

https://ejournal3.undip.ac.id/index.php/h istoriografi/article/view/27808

Farhan, A. (2018). Analisis Pemberdayaan Masyarakat Desa Wisata Candirejo Kecamatan Borobudur Kabupaten Magelang. Journal of Politic and 
Government Studies, 7(2), 1-28.

https://www.m-

culture.go.th/mculture_th/download/kin

g9/Glossary_about_HM_King_Bhumib

ol_Adulyadej's_Funeral.pdf

Fatima, W. Q., Khairunisa, L., Priatna, D. C., \& Prihatminingtyas, B. (2019).

Pembelajaran Bahasa Inggris Melalui

Media Game Pada Panti Asuhan Al

Maun Di Desa Ngajum. Seminar

Nasional Sistem Informasi, September, 1728. https://doi.org/2598-0076

Fauzanto, A. (2020). Problematika korupsi dana desa pada pelaporan dan pertanggungjawaban keuangan desa berdasarkan prinsip transparansi, akuntabilitas, dan partisipatif. Widya Yuridika: Jurnal Hukum, 3(1), 43-52.

Febriana, Y. E., \& Pangestuti, E. (2018). Analisis dampak pengembangan kepariwisataan dalam menunjang keberlanjutan ekonomi dan sosial budaya lokal masyarakat (Studi pada Desa Wisata Gubugklakah, Kecamatan Poncokusumo, Kabupaten Malang). Jurnal Administrasi Bisnis (JAB), 61(4), 143-150.

Fikri, Z., \& Septiawan, Y. (2020).

Pemanfaatan dana desa dalam pengembangan desa wisata di desa kurau barat 1.Zakiyudin. Ilmiah Politik, Kebijakan Dan Sosial, 2(1), 24-32.

Forstner, K. (2004). Community ventures and access to markets: The role of intermediaries in marketing rural tourism products. Development Policy Review, 22(5), 497-514. https://doi.org/10.1111/j.14677679.2004.00262.x

Ghatnekar, P. (2017). Persuasive technology in tourism online experiences and implications on tourist buying behaviour. University of Plymouth.
Gillis, A., \& Jackson, W. (2002). Research for nurses: methods and interpretation. F.A. Davis Co.

http://search.ebscohost.com/login.aspx? direct $=$ true $\&$ scope $=$ site $\& \mathrm{db}=$ nlebk $\& \mathrm{db}$ $=$ nlabk\&AN=82216

Giri, W. (2010). Sajen dan Ritual Orang Jawa. Penerbit Narasi.

Given, L. M. (2008). The Sage encyclopedia of qualitative research methods. Sage Publications.

Goenadhi, F., \& Rahadi, D. R. (2020). Who Is The Target Market Of Digital Tourism 4.0? FIRM Journal of Management Studies, 5(1), 50-61.

Goi, C. L. (2009). A review of marketing mix: 4Ps or more? International Journal of Marketing Studies, 1(1), 2.

Gordon, I., \& Champion, T. (2020). Towards a sustainable, negotiated mode of strategic regional planning: a political economy perspective. Regional Studies, $53,1-12$.

https://doi.org/10.1080/00343404.2020. 1759795

Hall, D., Kirkpatrick, I., \& Mitchell, M. (2005). Rural Tourism and Sustainable Business.

Halsall, D. (1992). Transport for tourism and recreation. Modern Transport

Geography., 155-177.

https://www.cabdirect.org/cabdirect/abst $\underline{\text { ract/19921850346 }}$

Harman, S. (2007). Importance of Destination Attributes Affecting Destination Choice of. Journal of Commerce \& Tourism Education Faculty, 1, 131-145.

Haryanto, J. T. (2014). Model

Pengembangan Ekowisata Dalam Mendukung Kemandirian Ekonomi 
Daerah Studi Kasus Provinsi Diy.

Jurnal Kawistara, 4(3).

https://doi.org/10.22146/kawistara.6383

Hermawan, H. (2017). Dampak

Pengembangan Desa Wisata

Nglanggeran Terhadap Ekonomi

Masyarakat Lokal. Jurnal Pariwisata,

III(2), 105-117.

https://doi.org/10.31219/osf.io/xhkwv

Ho, P.-T., \& Lee, C.-T. (2020). Constructing integrated rural tourism innovation development indicators. International Journal of Organizational Innovation, 12(4), 300-320. http://www.ijoionline.org/http://www.ijoi-online.org/

Hodge, B. (2006). The goddess tour: Spiritual tourism/post-modern pilgrimage in search of atlantis. Popular Spiritualities: The Politics of Contemporary Enchantment, 27.

Hodgson, P. (1990). New tourism product development. Tourism Management, 11(1), 2-5.

https://doi.org/10.1016/02615177(90)90002-q

Hwang, Y.-H., Gretzel, U., \& Fesenmaier, D. R. (2006). Multicity trip patterns: Tourists to the United States. Annals of Tourism Research, 33(4), 1057-1078.

Indrasari, Y. (2020). Efesiensi Saluran Distribusi Pemasaran Kopi Rakyat Di Desa Gending Waluh Kecamatansempol (Ijen) Bondowoso. Jurnal Manajemen Pemasaran, 14(1), 44-50. https://doi.org/10.9744/pemasaran.14.1. $\underline{44-50}$

Inskeep, E. (1991). Tourism planning: an integrated and sustainable development approach. Van Nostrand Reinhold.

Ira, W. S., \& Muhamad, M. (2020).

Partisipasi Masyarakat pada Penerapan Pembangunan Pariwisata Berkelanjutan
(Studi Kasus Desa Wisata Pujon Kidul, Kabupaten Magelang). Jurnal Pariwisata Terapan, 3(2), 124. https://doi.org/10.22146/jpt.43802

Jeffries, D. J. (1971). Defining the tourist product - and its importance in tourism marketing. The Tourist Review, 26(1), 2-5. https://doi.org/10.1108/eb057631

Kementerian Pariwisata. (2019). Buku Pedoman Desa Wisata. Kementerian Pariwisata.

Khasanah, S. A., \& Susilowati, E. (2017). Evaluasi pengetahuan tentang antibiotik sirup kering pada ibu di RW III Desa Ngajum, Kecamatan Ngajum, Kabupaten Malang. Farm-Klin, 2(1), 12.

Komarani, U., Satjapradja, O., \& Salampessy, M. L. (2015). Identifikasi dan Penilaian Obyek Daya Tarik Wisata Alam (Studi Kasus di Taman Nasional Ujung Kulon). Jurnal Nusa Sylva, 15(2), 35-41.

Kotler, Philip, \& Franke, G. (1990). Marketing: an introduction. PrenticeHall.

Kotler, Phillip, Bowen, J. T., Makens, J., \& Baloglu, S. (2017). Marketing for hospitality and tourism. Pearson Education.

Law, R., Li, G., Fong, D. K. C., \& Han, X. (2019). Tourism demand forecasting: A deep learning approach. Annals of Tourism Research, 75, 410-423.

Lee, C.-F. (2015). Tourist satisfaction with factory tour experience. International Journal of Culture, Tourism and Hospitality Research, 9(3), 261-277. https://doi.org/10.1108/IJCTHR-02$\underline{2015-0005}$

Lehto, X. Y., Lin, Y. C., Chen, Y., \& Choi, S. (2012). Family Vacation Activities 
and Family Cohesion. Journal of Travel and Tourism Marketing, 29(8), 835850.

https://doi.org/10.1080/10548408.2012. $\underline{730950}$

Leiper, N. (1990). Tourism Systems: An Interdisciplinary Perspective.

Department of Management Systems, Business Studies Faculty, Massey University. https://books.google.co.id/books?id=f5 XHAAAACAAJ

Lin, C.-H. (2020). Industrial tourism: moderating effects of commitment and readiness on the relationship between tourist experiences and perceived souvenir value. International Journal of Culture, Tourism and Hospitality Research, ahead-of-p(ahead-of-print). https://doi.org/10.1108/IJCTHR-02$\underline{2019-0027}$

Lohmann, G., Albers, S., Koch, B., \& Pavlovich, K. (2009). From hub to tourist destination-An explorative study of Singapore and Dubai's aviationbased transformation. Journal of Air Transport Management, 15(5), 205211.

MacDonald, C. (2012). Understanding PAR: A Qualitative Research Methodology. Canadian Journal of Action Research, 13(2), 34-50.

file:///C:/Users/Christelle/Downloads/37 -Article Text-89-1-1020120913.pdf\%0Ahttps://pdfs.semantic scholar.org/3b78/ecfe0b4a0a7591d2ea0 68c71e8ea320ff451.pdf

Maldonado-Erazo, C. P., del Río-Rama, M. de la C., Noboa-Viñan, P., \& ÁlvarezGarcía, J. (2020). Community-Based Tourism in Ecuador: Community Ventures of the Provincial and Cantonal Networks. Sustainability, 12(15), 6256. https://doi.org/10.3390/su12156256
Maulany, R. I., Putri, A. U. B., \& Achmad, A. (2018). Identifikasi potensi obyek ekowisata desa bonto masunggu, kecamatan tellu limpoe, kabupaten bone. Perennial, 14(1), 1. https://doi.org/10.24259/perennial.v14i1 .4997

Peraturan Menteri Kebudayaan dan Pariwisata Nomor KM.18/HM.001/MKP/2011 Tentang Pedoman Program Nasional Pemberdayaan Masyarakat (PNPM) Mandiri Pariwisata, Pub. L. No. Nomor KM.18/HM.001/MKP/2011, 1 (2011).

Merriam, S. B., \& Grenier, R. S. (2019). Qualitative Research in Practice: Examples for Discussion and Analysis. Wiley.

Morrison, A. M. (2013). Marketing and managing tourism destinations. In Marketing and Managing Tourism Destinations.

https://doi.org/10.4324/9780203081976

Neuman, W. L. (2014). Social Research Methods; Qualitative and Quantitative Approaches Seventh Edition. In Pearson. http://arxiv.org/abs/1210.1833\%0Ahttp: //www.jstor.org/stable/3211488?origin= crossref\%0Ahttp://www.ncbi.nlm.nih.g ov/pubmed/12655928

Panyik, E., Costa, C., \& Rátz, T. (2011). Implementing integrated rural tourism: An event-based approach. Tourism Management, 32(6), 1352-1363. https://doi.org/10.1016/j.tourman.2011. $\underline{01.009}$

Parsons, H., Mackenzie, S. H., \& Filep, S. (2020). New perspectives on tour guiding: Mediating spiritual tourist experiences. CAUTHE 2020: 20: 20 Vision: New Perspectives on the Diversity of Hospitality, Tourism and Events, 470. 
Parthasarathy, A., G, S., Bhanu, T., \& Unnikrishnan, H. (2020). Destinational Sustainability Analysis Through Netnography: Review on Hampi's Attraction, Accessibility and Amenities. SSRN Electronic Journal. https://doi.org/10.2139/ssrn.3678468

Peña, A. I. P., \& Jamilena, D. M. F. (2009). The relationship between business characteristics and ICT deployment in the rural tourism sector. The case of Spain. International Journal of Tourism Research, 12(1), n/a-n/a. https://doi.org/10.1002/jtr.735

Pomering, A., Noble, G., \& Johnson, L. (2008). A sustainability roadmap for contemporary marketing education: thinking beyond the 4Ps. Academy of Marketing Conference, Aberdeen, Scotland.

Pontoh, N. K., \& Kustiwan, I. (2009). Pengantar Perencanaan Perkotaan. In Bandung: Penerbit ITB. ITB PRESS. https://doi.org/10.1212/wnl.0000000000 $\underline{000212}$

Pradhana, A. O. (2012). Strategi pengembangan desa wisata Candirejo oleh koperasi desa wisata Candirejo kabupaten Magelang [UNS (Sebelas Maret University)].

https://digilib.uns.ac.id/dokumen/30719/

Strategi-pengembangan-desa-wisataCandirejo-oleh-koperasi-desa-wisataCandirejo-kabupaten-Magelang

Prasiasa, D., \& Damanik, D. (2010). Terasering Sawah Desa Wisata Jatiluwih Sebagai Daya Tarik Wisata: Kajian Estetika Post Modern. http://portal.kopertis3.or.id/handle/1234 $\underline{56789 / 1638}$

Undang-Undang RI No 6 Tahun 2014 Tentang Desa, Pub. L. No. UU RI No 6 Tahun 2014 Tentang Desa (2014).
Priyanto, P. (2016). Pengembangan Potensi Desa Wisata Berbasis Budaya Tinjauan Terhadap Desa Wisata Di Jawa Tengah. Jurnal Vokasi Indonesia, 4(1). https://doi.org/10.7454/jvi.v4i1.53

Pusat Bahasa Departemen Pendidikan Nasional, \& Tim Redaksi Kamus Besar Bahasa Indonesia. (2007). Kamus Besar Bahasa Indonesia. Balai Pustaka. https://opac.perpusnas.go.id/DetailOpac. aspx?id=345332

Rahmafitria, F., Pearce, P. L., Oktadiana, H., \& Putro, H. P. H. (2020). Tourism planning and planning theory: Historical roots and contemporary alignment.

Tourism Management Perspectives, 35, 100703.

https://doi.org/10.1016/j.tmp.2020.1007 $\underline{03}$

Rahman, K. M. (2016). Strategic Planning and Marketing Models'. Strategic Marketing Management in Asia. Emerald Group Publishing Limited, 59110.

Rasoolimanesh, S. M., Ramakrishna, S., Hall, C. M., Esfandiar, K., \& Seyfi, S. (2020). A systematic scoping review of sustainable tourism indicators in relation to the sustainable development goals. Journal of Sustainable Tourism. https://doi.org/10.1080/09669582.2020. 1775621

Remoaldo, P., Serra, J., Marujo, N., Alves, J., Gonçalves, A., Cabeça, S., \& Duxbury, N. (2020). Profiling the participants in creative tourism activities: Case studies from small and medium sized cities and rural areas from Continental Portugal. Tourism Management Perspectives, 36(September), 100746. https://doi.org/10.1016/j.tmp.2020.1007 $\underline{46}$ 
Richards, G., \& Raymond, C. (2000). Creative tourism. ATLAS News, 23(8), 16-20.

Rini, W. S. D., \& Tarigan, M. I. (2020). Pemanfaatan Wisata Mata Air yang Dikelola oleh BUMDES di Desa Belik. Jurnal Pengabdian Dan Peningkatan Mutu Masyarakat, 1(1), 75-81. https://doi.org/10.22219/janayu.v1i1.11 $\underline{481}$

Sautter, E. T., \& Leisen, B. (1999). MANAGING STAKEHOLDERS A Tourism Planning Model. In Annals of Tourism Research (Vol. 26, Issue 2).

Schiefelbusch, M., Jain, A., Schäfer, T., \& Müller, D. (2007). Transport and tourism: roadmap to integrated planning developing and assessing integrated travel chains. Journal of Transport Geography, 15(2), 94-103. https://doi.org/10.1016/j.jtrangeo.2006.1 2.009

Scuttari, A., Lucia, M. Della, \& Martini, U. (2013). Integrated planning for sustainable tourism and mobility. A tourism traffic analysis in Italy's South Tyrol region. Journal of Sustainable Tourism, 21(4), 614-637. https://doi.org/10.1080/09669582.2013. 786083

Shikida, A., Yoda, M., Kino, A., \& Morishige, M. (2010). Tourism Relationship Model and Intermediary for Sustainable Tourism Management: Case Study of the Kiritappu Wetland Trust in Hamanaka, Hokkaido. Tourism and Hospitality Research, 10(2), 105115. https://doi.org/10.1057/thr.2009.29

Sholikhin, M. (2010). Misteri bulan Suro: perspektif Islam Jawa. Penerbit Narasi.

Sita Dewi, N. L. D. A., \& Yulaika, A. (2019). Analisis faktor yang mempengaruhi perkembangan motorik halus pada anak usia prasekolah di tk ra diponegoro desa ngajum kabupaten malang. Jurnal Kesehatan

Mesencephalon, 5(2).

https://doi.org/10.36053/mesencephalon .v5i2.181

Smith, S. L. J. (1994). The tourism product. Annals of Tourism Research, 21(3), 582-595. https://doi.org/10.1016/01607383(94)90121-X

Song, H., Qiu, R. T. R., \& Park, J. (2019). A review of research on tourism demand forecasting: Launching the Annals of Tourism Research Curated Collection on tourism demand forecasting. Annals of Tourism Research, 75, 338-362.

Sriwi, A., \& Hulfa, I. (2019). Identifikasi potensi wisata desa selong belanak kabupaten lombok tengah. Hospitality, $8(2)$

Streubert, H. J., Speziale, H. S., \& Carpenter, D. R. (1995). Qualitative Research in Nursing: Advancing the Humanistic Imperative. Lippincott. https://books.google.co.id/books?id=_R $\underline{\text { 1tAAAAMAAJ }}$

Subehi, F., Luthfi, A., Mustofa, M. S., \& Gunawan, G. (2020). Peran Badan Usaha Milik Desa (BUMDes) dalam Peningkatan Kesejahteraan Masyarakat Di Desa Ponggok, Kabupaten Klaten. Umbara: Indonesian Journal of Anthropology, 5(1), 34-43. https://doi.org/10.24198/umbara.v3i1.25 $\underline{670}$

Sulistyawati, A. S. (2010). Pengembangan Desa Wisata Kendran sebagai Daya Tarik Wisata di Kecamatan Tegalalang. Jurnal Ilmiah Hospitality Management, 1(1).

Sunardi, N., \& Lesmana, R. (2020). Pelaksanaan alokasi dana desa terhadapmanajemen keuangan desa 
dalam meningkatkan efektivitas program desa sejahtera. Jurnal Sekuritas, 3(1), 277-288.

Susyanti, D. W., \& Latianingsih, N. (2013). Potensi Desa melalui Pariwisata Pedesaan. Ekonomi Dan Bisnis, 12(1), $33-36$.

Sutedjo, A. (2019). Identifikasi potensi desa mojo kecamatan kalitidu kabupaten bojonegoro sebagai desa wisata berdasarkan community based tourism. Jurnal Geografi, XVII(2), 65-78.

Swarbrooke, J. (2002). The Development and Management of Visitor Attractions (2nd ed.). Butterworth-Heinemann.

Swarbrooke, J., \& Horner, S. (2007). Consumer behaviour in tourism. Routledge.

Tan, S.-K., Kung, S.-F., \& Luh, D.-B. (2013). A model of 'creative experience' in creative tourism. Annals of Tourism Research, 41, 153-174.

Tang, C., Weaver, D., \& Lawton, L. (2017). Can stopovers be induced to revisit transit hubs as stayovers? A new perspective on the relationship between air transportation and tourism. Journal of Air Transport Management, 62, 5464.

Tanti, A., \& Buhalis, D. (2017). The influences and consequences of being digitally connected and/or disconnected to travellers. Information Technology \& Tourism, 17(1), 121-141. https://doi.org/10.1007/s40558-017$\underline{\text { 0081-8 }}$

The World Tourism Conference. (1980). Manila Declaration on World Tourism. The World Tourism Conference, October, 1-4.
Tomej, K., \& Liburd, J. J. (2020).

Sustainable accessibility in rural destinations: a public transport network approach. Journal of Sustainable Tourism, 28(2), 222-239. https://doi.org/10.1080/09669582.2019. $\underline{1607359}$

Tosun, C., \& Timothy, D. J. (2001).

Shortcomings in planning approaches to tourism development in developing countries: the case of Turkey. International Journal of Contemporary Hospitality Management, 13(7), 352359.

https://doi.org/10.1108/0959611011040 3910

Tóth, G., \& Dávid, L. (2010). Tourism and accessibility: An integrated approach. Applied Geography, 30(4), 666-677. https://doi.org/10.1016/j.apgeog.2010.0 $\underline{1.008}$

Truong, T.-H., \& King, B. (2009). An evaluation of satisfaction levels among Chinese tourists in Vietnam. International Journal of Tourism Research, 11(6), 521-535. https://doi.org/10.1002/jtr.726

Tyas, N. W., \& Damayanti, M. (2018). Potensi Pengembangan Desa Kliwonan sebagai Desa Wisata Batik di Kabupaten Sragen. Journal of Regional and Rural Development Planning, 2(1), 74. https://doi.org/10.29244/jp2wd.2018.2.1 $.74-89$

UIN Sunan Ampel Surabaya. (2015). Community based Research - Panduan Merancang dan Melaksanakan Penelitian Bersama Komunitas. Lembaga Penelitian dan Pengabdian Kepada Masyarakat Uin Sunan Ampel Surabaya.

UU Nomor 10 Tahun 2009 tentang Kepariwisataan, (2009) (testimony of UU Nomor 10 Tahun 2009 tentang 
Kepariwisataan).

https://doi.org/10.TAHUN

Väänänen, E., \& Komppula, R. (2020).

SUSTAINABLE TOURISM

DESTINATION MANAGEMENT

Multiple case study from Lapland

Sustainable tourism destination

management [UNIVERSITY OF

EASTERN FINLAND].

https://epublications.uef.fi/pub/urn_nbn

fii_uef-20200894/urn_nbn_fi_uef-

20200894.pdf

Valsa, K. (2005). Action research for improving practice - A Practical Guide. In A SAGE Publication Campany (Vol. 36, Issue 6). Paul Chapman Publishing.

Wall, G. (2020). From carrying capacity to overtourism: a perspective article. https://doi.org/10.1108/TR-08-2019$\underline{0356}$

Wang, M., Chen, L.-H., Su, P., \& Morrison, A. M. (2019). The right brew? An analysis of the tourism experiences in rural Taiwan's coffee estates. Tourism Management Perspectives, 30, 147-158.

Wardani, D. K., \& Utami, R. R. P. (2020). Pengaruh Transparansi Pengelolaan Keuangan Dana Desa Dan Pemberdayaan Masyarakat Terhadap Kesejahteraan Masyarakat Desa Sidoharjo. Kajian Bisnis STIE Widya Wiwaha, 28(1), 35-50. https://doi.org/10.32477/jkb.v28i1.376

Wearing, S., \& Mc Donald, M. (2002). The development of community-based tourism: Re-thinking the relationship between tour operators and development agents as intermediaries in rural and isolated area communities. Journal of Sustainable Tourism, 10(3), 191-206. https://doi.org/10.1080/0966958020866 $\underline{7162}$
Wulandari, A., \& Adikampana, I. M. (2018). Pengelolaan Taman Mumbul Sebagai Daya Tarik Wisata Spiritual Di Desa Sangeh, Kecamatan Abiansemal, Kabupaten Badung. Jurnal Destinasi Pariwisata, 5(2), 369. https://doi.org/10.24843/jdepar.2017.v0 5.i02.p30

Yusrizal, F., \& Asmoro, A. Y. (2020). Dampak sosial budaya pariwisata: masyarakat majemuk, konflik dan integrasi sosial di yogyakarta. Jurnal Pariwisata, 7(2), 92-105. https://doi.org/https://dx.doi.org/10.313 11/par.v7i2.8559

\section{BIODATA PENULIS}

Agung Yoga Asmoro, memperoleh gelar Sarjana Sains Terapan Pariwisata dan Magister Manajemen Pariwisata dari Sekolah Tinggi Pariwisata Bandung. Saat ini aktif sebagai dosen Akademi Pariwisata Nasional Banjarmasin dengan NIDN 1130017901, dosen LB di STP Satya Widya Surabaya. pengelola biro perjalanan wisata https://lintangbuanatours.com dan tenaga ahli pariwisata pada beberapa konsultan pariwisata.

Thamrin B. Bachri, merupakan Direktur Jenderal Pemasaran Pariwisata dan Kerjasama Luar Negeri, DEPBUDPAR RI (2003-2008) menamatkan Pendidikan di Postgrad School of Hospitality and Tourism University of Wisconsin-Stout, USA (1990) dan alumni LEMHANAS KSA Angkatan X Tahun 2002. Karir panjang dan luasnya sejak 1980, kini mengajar di Sekolah Tinggi Pariwisata Bandung.

Alditia Detmuliati, menamatkan D4 dari Universitas Riau pada tahun 2014, dan melanjutkan studi di Program Pascasarjana Sekolah Tinggi Pariwisata Bandung dan lulus pada tahun 2016. Sempat menjadi tenaga pengajar di Akademi Pariwisata NHI Bandung pada tahun 2017. Saat ini terdaftar sebagai dosen tetap di 
Politeknik Negeri Sriwijaya dengan NIDN

0408069202. 